\title{
Enteral Nutrition in Patients with Inflammatory Bowel Disease. Systematic Review, Meta-Analysis, and Meta-Regression
}

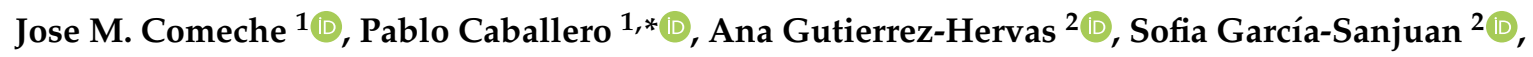 \\ Iris Comino $^{1}\left(\mathbb{D}\right.$, Cesare Altavilla ${ }^{1}\left(\mathbb{D}\right.$ and Jose Tuells ${ }^{1}(\mathbb{D}$ \\ 1 Department of Community Nursing, Preventive Medicine and Public Health and History of Science (SPAIN), \\ University of Alicante, San Vicente del Raspeig, 03690 Alicante, Spain; \\ josemiguelcomeche@gmail.com (J.M.C.); iriscomino@gmail.com (I.C.); eatingfaster@gmail.com (C.A.); \\ tuells@ua.es (J.T.) \\ 2 Department of Nursing (SPAIN), University of Alicante, San Vicente del Raspeig, 03690 Alicante, Spain; \\ ana.gutierrez@ua.es (A.G.-H.); sofia.garcia@ua.es (S.G.-S.) \\ * Correspondence: pablo.caballero@ua.es
}

Received: 30 August 2019; Accepted: 25 October 2019; Published: 4 November 2019

check for updates

\begin{abstract}
Inflammatory bowel disease (IBD) is a chronic disease mediated by the immune system and is characterized by inflammation of the gastrointestinal tract. One of the possible treatments for this pathology is a change in the type of diet, of which enteral nutrition (EN) is one. This study is to understand how the use of EN can affect the adult population diagnosed with IBD. We conducted a systematic review, meta-analysis, and a meta-regression. On the different databases (MEDLINE, Scopus, Cochrane, LILACS, CINAHL, WOS), we found 363 registers with an accuracy of $12 \%$ (44 registers). After a full-text review, only 30 research studies were selected for qualitative synthesis and 11 for meta-analysis and meta-regression. The variables used were Crohn's disease activity index (CDAI), C-reactive protein (CRP), and erythrocyte sedimentation rate (ESR). EN has been shown to have efficacy for the treatment of Crohn's disease and is compatible with other medicines. As for the CDAI or rates of remission, there were no differences between enteral and parenteral nutrition. Polymeric formulas have shown better results with respect to the CRP. The long-term treatment could dilute the good CDAI results that are obtained at the start of the EN treatment.
\end{abstract}

Keywords: inflammatory bowel diseases; enteral nutrition; systematic review; meta-analysis; Crohn's disease

\section{Introduction}

Inflammatory bowel disease (IBD) is a chronic disease mediated by the immune system and characterized by the inflammation of the gastrointestinal tract. IBD includes Crohn's disease (CD) as well as ulcerative colitis (UC) [1]. UC affects the large intestine and is generally observed as a superficial ulcer due to an inflammatory reaction localized to the mucosa and the submucosa. However, CD occurs all along the intestinal tract (from mouth to anus) and involves the entire intestinal layer [2].

The prevalence and incidence of IBD has increased worldwide and is increasingly diagnosed in young individuals [3]. As it is a chronic, incurable, and low-mortality disease, it is expected that the decrease of the global burden of the disease in the next decade will require a two-pronged solution that implies research on prevention interventions as well as innovations in the care of these patients $[3,4]$.

The etiology of IBD is still greatly unknown, and recent evidence indicates that the genetic susceptibility of the individual, the environment, the intestinal microbial flora, and the immune responses are all factors that are involved and functionally integrated in the pathogenesis of IBD [5]. 
IBD can provoke various symptoms that include abdominal pain, low fever, fatigue, weight loss, diarrhea, bloody feces, etc. [6].

Within the identification of the environmental risk factors, diet is one of the most important as it regulates intestinal inflammation by modifying the intestinal microbiota, which has an effect on the gastrointestinal permeability $[7,8]$. Therefore, it can induce the expression of disease genes and determine the cell's phenotype and function in $\operatorname{IBD}[7,8]$. One of the possible treatments for this pathology is a change in the type of diet [9].

One of the potential changes in diet is the use of enteral nutrition (EN), which is based on the administration of enteral foods/formulas through different means. These foods are nutritionally-complete liquid mixtures of pre-digested foods that have carbohydrates such as simple sugars, fats such as different types of oils, and nitrogen as protein, along with vitamins and minerals [10]. Within the elemental formulas, different classes can be distinguished as a function of the nitrogen source: elemental formulas are based on amino acids, semi-elemental formulas are based on oligo-peptides, and polymeric formulas are based on whole proteins [11].

Diverse authors have highlighted that EN, especially in the form of exclusive enteral nutrition (EEN), is a type of therapy established to induce the remission of $C D$ in the infant population, although its role as a first line therapy for $\mathrm{CD}$ in adults has not been defined yet and its mechanism of action for palliating the symptoms of IBD is not completely understood $[9,12]$. Authors such as Guagnozzi et al. suggest that the interaction between the composition of specific dietary formulas or nutrients and IBD should be investigated to add new knowledge to the etiopathogenesis of the disease in nutritional intervention [13].

Therefore, the main objective of this study was to understand how the use of EN can affect the adult population diagnosed with IBD.

\section{Materials and Methods}

To achieve this objective, a systematic review was conducted in agreement with the procedures and verification list described by PRISMA [14]. Afterward, a meta-analysis on the more common results and a meta-regression with the co-variables, type of enteral nutrition, and period of treatment, were conducted.

\subsection{Systematic Review}

A search of scientific works was conducted in the MEDLINE database through the system of open retrieval system on the Internet such as PubMed, Cochrane, Scopus, Web of Science, CINAHL, and LILACS. Studies conducted over time up to 5 January 2019 were compiled.

\subsubsection{Inclusion and Exclusion Criteria}

The studies selected had to comply with the following inclusion criteria: refer to an adult population (older than 18) diagnosed with some type of IBD; study the effect of enteral nutrition within IBD; were clinical trials; and in the English, Spanish, Portuguese, French, or German languages.

The following articles were excluded: those that referred to the infant population; to animals, to the use of EN in a healthy adult population; those that sought the effect of oral exclusion diets on IBD; observational studies; and those based on secondary sources.

\subsubsection{Search Equation}

To include content linked to the intervention EN, a specific descriptor was used (MeSH) such as "Enteral Nutrition", and the term "Enteral Nutrition" in the title or abstract.

For the content linked to the population, we utilized the descriptor that referred to the disease "Inflammatory bowel diseases", and its equivalent term in the title or abstract.

Additionally, the filters "Humans", "Adult", and "Clinical Trial" were utilized to achieve our objective. 
Therefore, the main search equation designed for this study was:

((“Inflammatory Bowel Diseases”[Mesh] OR “Inflammatory Bowel Diseases"[Title/Abstract]) AND ("Enteral Nutrition”[Mesh] OR “Enteral Nutrition"[Title/Abstract])) AND (Clinical Trial[ptyp] AND Humans[Mesh] AND adult[MeSH])

The search equation was adapted to each and all of the databases described previously. The process was conducted between the months of May and June, 2019.

\subsubsection{Selection Process}

After eliminating the duplicate records, the process of selection was conducted in two phases. The first consisted of reviewing the titles and abstracts of all the article records that resulted from the adapted search equations and were shown by the databases by using the inclusion and exclusion criteria and the objective of the study as the screening measure. The screening and selection of the records/articles were conducted independently by the two researchers, both experts in the fields of nutrition. These researchers agreed on the discrepancies found in order to define the final suitability of the records/articles found in the databases. The precision of the search was calculated, based on the ratio of the full-text articles selected for the review, divided by the number of records found by the search equation, and multiplied by one hundred.

The second phase was conducted by applying the inclusion/exclusion criteria to the complete texts of all of the scientific studies selected in the first phase, thus ensuring the relevance of each one. In order to obtain studies that were not accessible via the Internet, we used three methods: Researchgate, the correspondence author, and interlibrary loan. Only three were recovered through interlibrary loan.

\subsubsection{Evaluation of the Quality of the Studies}

The evaluation of the methodological quality of the included studies was performed by two independent researchers by using the Cochrane risk of bias tool (RoB 2) for clinical trials [15]. This tool is structured into five domains through which bias might be introduced into the result: the randomization process, deviations from intended interventions, missing outcome data, measurement of the outcome, and selection of the reported results. For each study, the response options for an overall risk-of-bias judgement were "low risk of bias", "some concerns", and "high risk of bias".

\subsection{Meta-Analysis and Meta-Regression}

To calculate the effect size of the enteral nutrition on the variables: the Crohn's disease activity index (CDAI), C-reactive protein (CRP), and erythrocyte sedimentation rate (ESR), a meta-analysis, were performed. For this, the model of fixed effects and the model of random effects were utilized. The results were presented as a forest-plot, along with the percent heterogeneity and its confidence interval at $95 \%$, the $\mathrm{T}$ value, and the heterogeneity test.

To explore the influence of each study over the effect size, we used a leave-one-out method; pooled estimates were calculated by omitting one study at a time. In addition, we plotted a scatter plot introduced by Baujat et al. [16] On the $x$-axis, the contribution of each study to the overall heterogeneity statistic was plotted. On the $y$-axis, the standardized difference of the overall treatment effect with and without each study was plotted; this quantity describes the influence of each study on the overall treatment effect. Therefore, studies that fell in the top right quadrant of the Baujat plot had the most influence.

Publication bias occurs when only favorable results are published, and this could have consequences on the results of the meta-analyses if these were included. To analyze the publication bias, a non-parametric analysis was conducted as proposed by Duval and Tweedie [17], based on the funnel-plot, estimating and adjusting for the number and outcomes of missing studies in the meta-analysis. Another less-conservative proposal to estimate the number and outcomes of missing studies was proposed by Copas et al. [18]. 
The meta-regression was utilized to understand if the type of enteral nutrition (polymeric or elemental), age (years), or the duration of the intervention (days) modified the effect size of the resulting variables CDAI, CRP, and ESR as a function of the type of nutrition. All the calculations were conducted within an R programming environment by utilizing the packages meta version 4.9-6 [19] and metasens version 0.4-0 [20].

\section{Results}

\subsection{Systematic Review}

As a result of the specific search equations used on the different databases, a total of 438 records of scientific articles were found. A total of 75 records were duplicated, leaving a total of 363 records without duplication. In the first phase of the study, exactly 319 study records were discarded, leaving 44 full-text studies to review, so the accuracy was $12 \%$. The reasons for not including them were that 131 records showed that the study utilized a design that was not adequate, 100 did not use an adult population, 50 did not study the effect of EN, three were written in another language other than the ones cited above, (two in Japanese and one in Chinese), 12 did not refer to humans, six did not refer to the IBD, and 17 were conducted without showing results (Figure 1).
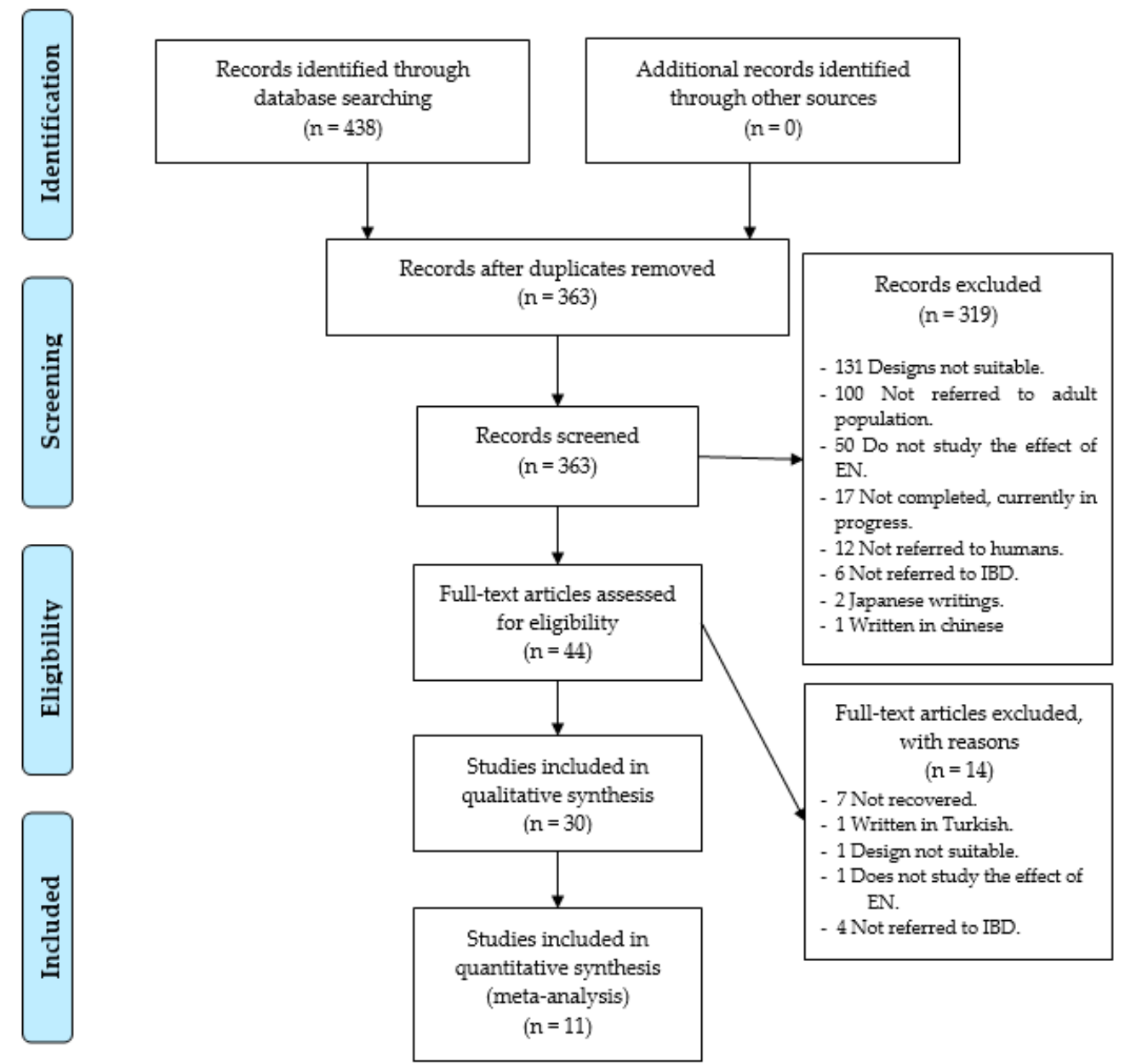

Figure 1. Identification and selection of the studies/records in the databases.

In the second phase, seven studies were not utilized as they could not be obtained in electronic format, not even after using the methods explained in the methodology. In addition, seven trials were removed, one for being written in Turkish, another due to defects in its design, another for not 
studying the effects of EN, and four because the population studied was not diagnosed with IBD. Therefore, only 30 research studies [10,21-49] were selected, as shown in Figure 1.

As for the designs of the studies included, 16 controlled and randomized clinical studies (53.3\%), nine non-randomized, controlled clinical trials $(30 \%)$, and five non-randomized, non-controlled clinical trials $(16.7 \%)$ were found. In addition, 28 of the studies found showed results that specifically referred to $C D$, and two studies had results on UC and CD, under the category of IBD. Additionally, 23 studies mentioned results of the disease in its active form, four studies in the shape of remission, and the rest did not indicate any. Figure 2 shows this information in a chronological manner.

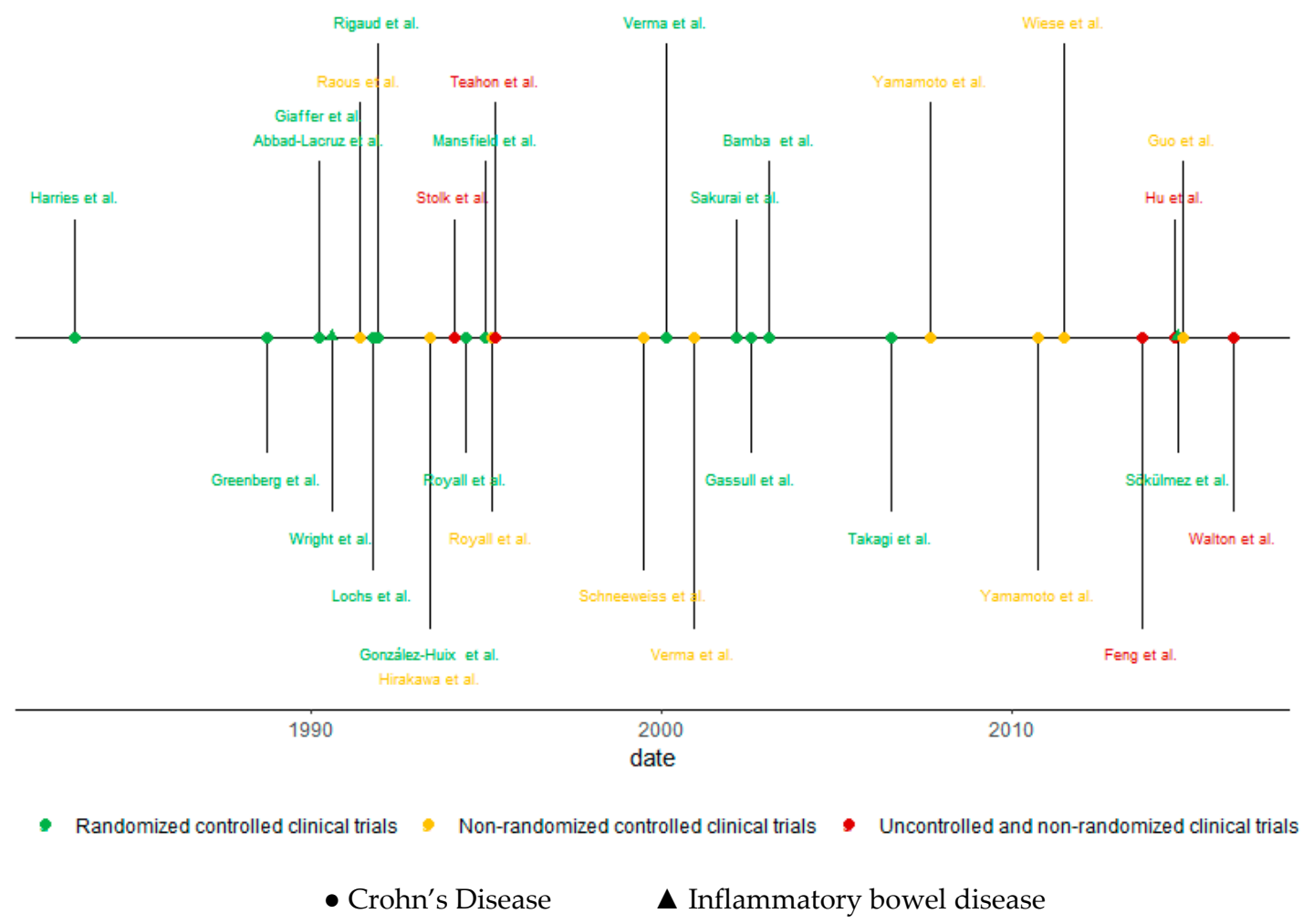

Figure 2. Chronological review according to the type of study and population.

As for the variety of the types of formulas employed, 19 studies utilized an elemental formula, 11 studies utilized a polymeric formula, two studies a semi-elemental formula, and three studies a type of parenteral nutrition (PN). Likewise, it should be mentioned that various types of formulas were often used in the same study. Thus, the following commercial formulas were employed: "E028", “Novasource", “Peptisorb", “Elental", "E028 Extra", "Vivonex-TEN", “Peptison", "Peptamen", "Vivonex HN", "Realmentyl", "Triosrbon", "Vital", "Vivonex", "Fortison", "Precision-Isotonic", "Uniasa", "Guarantee Plus", and "liquid Pepti-2000 LF".

In addition, a total of six types of objectives were found: 10 studies sought to compare two different types of EN, among which five of the works compared an elemental formula with a polymeric one, two compared an elemental formula with another elemental one that contained a greater concentration of fats, one work compared two types of polymeric formulas, one work compared two types of elemental formulas, and one work compared an elemental formula with a semi-elemental one.

Moreover, seven studies compared a type of EN with an oral diet, five studies sought to experiment with a type of EN, three studies compared a type of EN with a type of PN, three studies sought to compare a type of EN with another type of medication plus an oral diet, and finally, two studies sought to compare a partial EN plus a diet with an oral diet. 
As for the manner of administration of the EN, 15 research studies employed a nasogastric tube, three studies utilized a nasoduodenal catheter, two studies used a nasointestinal catheter, seven studies administered the formula orally, and three did not specify the manner of administration.

The total population analyzed in the research studies found included a total of 1070 individuals with IBD, with 1016 diagnosed with CD and 25 with UC.

The main tools utilized by the researchers to obtain results were scores, biomarkers, and tests to measure the activity of the disease: "Harvey-Bradshaw Index" (HBI), the CDAI, the Van Hees activity index (VHAI), the qualification in the classification of the International Organization of Inflammatory Bowel Disease (IOIBD), the Subjective Global Assessment (SGA), the Truelove and Witts index, the simple clinical index, the Crohn's disease activity score (CDAS); biomarkers such as CRP, ESR, the white blood cell count (WBC), levels of albumin, pre-albumin, transferrin, hemoglobin, platelet count, total bilirubin, alkaline phosphatase, etc.; and medical tests such as ileocolonoscopy. Specific quality of life questionnaires such as the "Inflammatory Bowel Disease Questionnaire" (IBDQ) were also used as were complementary tests such as urine and feces samples and tests to measure the body's composition such as anthropometries and bioimpedence.

Table 1 shows the main results schematically, as found in the selected articles. Figures 3 and 4 show the scores obtained by the studies for their methodological quality, according to the Cochrane risk of bias tool.

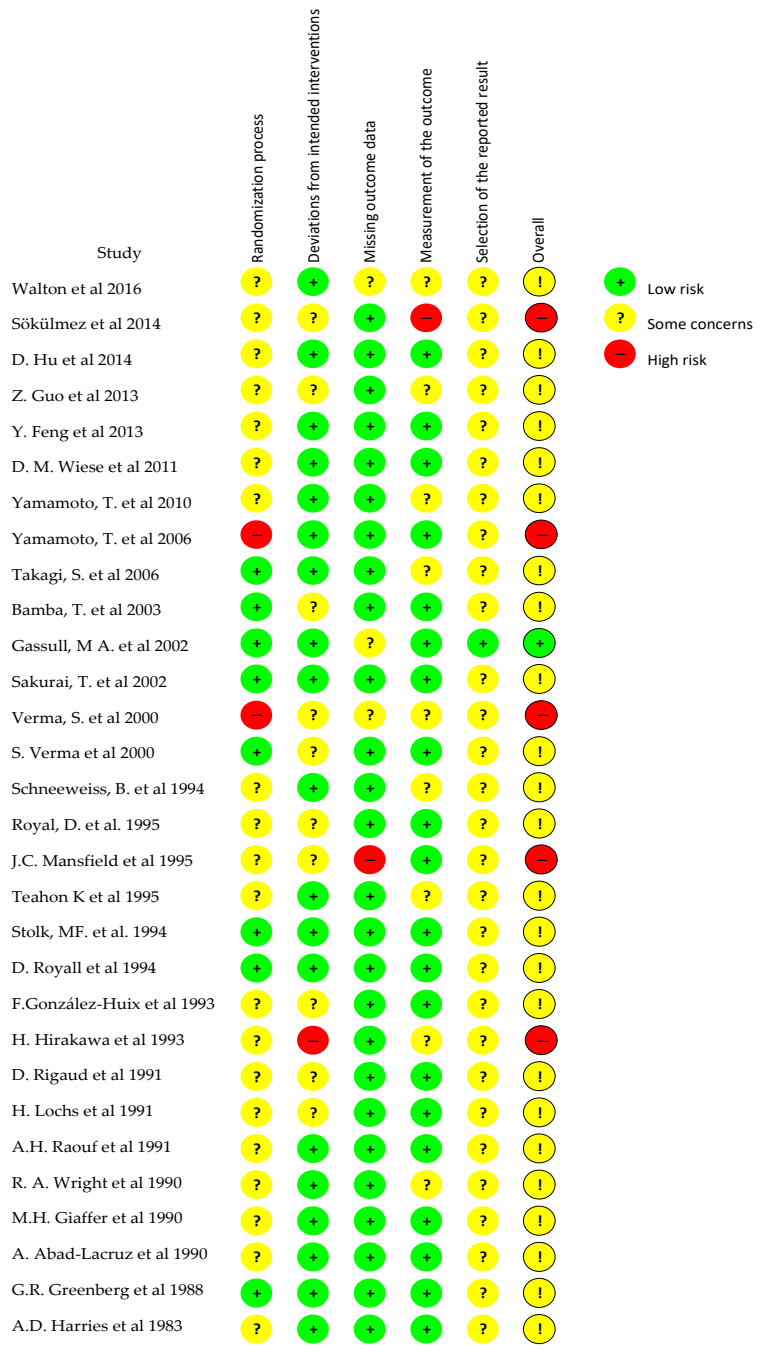

Figure 3. Risk of bias summary across the clinical trials. Low risk of bias: green "+"; Some concerns of bias: yellow "?", “!”; High risk of bias: red "-". 
Table 1. Main results of the systematic review.

\begin{tabular}{|c|c|c|c|c|c|c|c|c|}
\hline Author & Study & $n$ /age & Disease & $\mathrm{P} / \mathrm{d}$ & $\mathrm{CC}$ & Treatment & Variables & Main Results \\
\hline Walton et al. 2016 [10] & UNRCT & $17 /-$ & $\begin{array}{l}\text { ACT } \\
\text { CD }\end{array}$ & 14 & GB & $\begin{array}{l}\text { Enteral feeding E028 extra } \\
\text { (Elementary diet) }\end{array}$ & $\begin{array}{l}\text { CRP, HBI and automated } \\
\text { spectral identification in feces }\end{array}$ & $\begin{array}{l}\text { The HBI decreased from } 6.88 \pm 2.93 \text { to } 4 \pm 5.50,(p<0.05) \text {, the CRP from } 36.0 \\
\pm 41.3 \mathrm{mg} / \mathrm{L} \text { to } 8.11 \pm 3.59(p<0.05) \text {, the concentration of } 1 \text {-propanol and } \\
\text { 1-butanol decreased too. No modifications in phenol and indole. The SCFA } \\
\text { esters disappeared. }\end{array}$ \\
\hline $\begin{array}{l}\text { Pinar Sökülmez et al. } \\
2014 \text { [21] }\end{array}$ & RCCT & $\begin{array}{l}38 / 37 \\
\text { M } 28 \\
\text { F } 10\end{array}$ & $\begin{array}{l}\text { ACT } \\
\text { IBD } \\
\text { EG/CG: } 15 / 23 \\
\text { CD } \\
\text { EG/CG: } 6 / 7 \\
\text { UC } \\
\text { EG/CG: } 9 / 16\end{array}$ & 21 & $\mathrm{TR}$ & $\begin{array}{l}\text { EG/CG } \\
\text { Diet and EN } \\
\text { Novasource }{ }^{\circledR} / \text { Unrestricted } \\
\text { Diet }\end{array}$ & $\begin{array}{l}\text { SGA, BMI, nausea, vomiting, } \\
\text { bowel movements, change in } \\
\text { malnutrition state, general } \\
\text { status, and disease severity. }\end{array}$ & $\begin{array}{l}\text { Although at the beginning of the study the proportion of patients with a } \\
\text { severe UC in the EG was higher than in the CG ( } 8 / 9 \text {, and } 7 / 16 \text { respectively) } \\
\text { there were no significant differences at the end of the study }(p>0.05) \text {. In } \\
\text { both groups the improvements in disease activity of patients with UC were } \\
\text { significant, but non-significant positive changes were observed in the } \\
\text { clinical findings during the hospitalization period. Significant } \\
\text { improvements of the SGA in both groups. }\end{array}$ \\
\hline $\begin{array}{l}\text { Dong Hu et al. } \\
2014 \text { [22] }\end{array}$ & UNRCT & $\begin{array}{l}59 / 32 \\
\text { M } 42 \\
\text { F } 17\end{array}$ & $\begin{array}{l}\text { ACT } \\
\text { CD }\end{array}$ & 84 & $\mathrm{CN}$ & $\begin{array}{l}\text { Elemental formula Peptide } \\
\text { (Nutricia) through nasogastric } \\
\text { or nasointestinal tube, plus } \\
\text { water and weak tea. }\end{array}$ & $\begin{array}{l}\text { Symptoms, CDAI, peripheral } \\
\text { blood samples. Laboratory } \\
\text { tests, including nutritional } \\
\text { parameters and inflammatory } \\
\text { parameters and CT. }\end{array}$ & $\begin{array}{l}50 \text { patients achieved a partial remission, } 30 \text { a complete remission. } 48 \\
\text { symptomatic remission, } 35 \text { radiological remission and } 42 \text { clinical remission } \\
\text { The CDAI decreased from } 188.2 \text { to } 132.4 \text { in } 21 \text { days }(p<0.05) \text {, and to } 92.9 \\
\text { after } 81 \text { days }(p<0.05) \text {. Significant decrease in the thickness of the intestinal } \\
\text { wall and an increase in the area of the luminal cross section. CRP and ESR } \\
\text { decreased significantly ( } p<0.05) \text {, the BMI, albumin, prealbumin and } \\
\text { transferrin, HB, platelets, red blood cells, globulin and total protein } \\
\text { increased significantly }(p<0.05) \text {. }\end{array}$ \\
\hline $\begin{array}{l}\text { Zhen Guo et al. } \\
2013[23]\end{array}$ & UNRCT & $\begin{array}{l}13 / 26 \\
\mathrm{M}=9 \\
\mathrm{~F}=4\end{array}$ & $\begin{array}{l}\text { ACT } \\
\text { CD }\end{array}$ & 28 & $\mathrm{CN}$ & $\begin{array}{l}\text { Exclusive EN through polymer } \\
\text { formula Administration: } \\
\text { Nasogastric tube at night and } \\
\text { orally by day. They allowed } \\
\text { water consumption. }\end{array}$ & $\begin{array}{l}\text { IBDQ, CDAI, BMI, CRP, ESR, } \\
\text { WBC count, HB and serum } \\
\text { albumin level in peripheral } \\
\text { venous blood. }\end{array}$ & $\begin{array}{l}11 \text { patients achieved clinical remission and } 2 \text { did not. CDAI and CRP } \\
\text { decreased from } 232.2 \text { and } 34.6 \text { to } 84.7 \text { and } 4.0 \text { ( }(p \leq 0.001) \text {. Significantly } \\
\text { decreased the number of liquid or soft stools, abdominal pain, general } \\
\text { well-being and percentage deviation of the standard weight }(p<0.05) \text {, no } \\
\text { differences were found in the presence of complications, taking } \\
\text { atropine/diphenoxylate or opiates, presence of a mass abdominal and } \\
\text { hematocrit. There were significant improvements in the IBDQ, from } 128.3 \text { to } \\
182.9(p<0.001) \text {. Significant improvement in all categories: intestinal } \\
\text { symptoms (from } 41.5 \text { to } 62.0, p<0.001) \text {, systemic symptoms }(16.5 \text { to } 27.5 \text {, } \\
p<0.001) \text {, social function (20.5 to } 26.5, p=0.03) \text { and emotional state }(49.8 \text { to } \\
66.9, p<0.001) \text {. Correlation between IBDQ and CDAI after treatment } \\
(\mathrm{r}=-0.57 ; p=0.042) \text {. }\end{array}$ \\
\hline Feng Y et al. 2013 [24] & NRCCT & $\begin{array}{l}24 / 33 \\
\text { M } 17 \\
\text { F } 7\end{array}$ & $\begin{array}{l}\text { ACT } \\
\text { CD } \\
\text { ENG/NoEN/CG } \\
8 / 8 / 8\end{array}$ & 28 & $\mathrm{CN}$ & $\begin{array}{l}\text { ENG: Enteral formula } \\
\text { "Peptisorb" by nasogastric } \\
\text { tube, plus water. NoENG: EC } \\
\text { patients without EN. CG: } \\
\text { Patients with colon carcinoma. }\end{array}$ & $\begin{array}{l}\text { Adipocyte size, adipokine } \\
\text { production and level of CRP } \\
\text { were evaluated. Leptin, } \\
\text { resistin, TNF, and IL-6 and } \\
\text { IL-10 levels were determined. } \\
\text { BMI, CDAI, etc. were } \\
\text { calculated. }\end{array}$ & $\begin{array}{l}\text { ENG patients had a higher BMI level and lower levels of CRP and CDAI } \\
(p<0.001) \text { and achieved clinical remission (CDAI }<150) \text {. In addition, } \\
\text { protein levels of proinflammatory adipokines (TNF-alpha and leptin) were } \\
\text { lower, leptin was negatively regulated, and adipokine expression (mRNA } \\
\text { level) was positively regulated. In the NoEN group the level of adiponectin } \\
\text { protein was higher }\end{array}$ \\
\hline $\begin{array}{l}\text { Dawn M. Wiese et al. } \\
2011 \text { [25] }\end{array}$ & NRCCT & $\begin{array}{l}20 / 46 \\
\text { M } 4 \\
\text { F } 16\end{array}$ & $\begin{array}{c}\mathrm{ACT} \\
\mathrm{CD} \\
\mathrm{EPA}>2 \% / \mathrm{EPA}<2 \% \\
10 / 10\end{array}$ & 120 & US & $\begin{array}{l}\text { Two 8-oz each day of NE } \\
\text { EPA }>2 \% \text { or EPA }<2 \% \\
\text { respectively. }\end{array}$ & $\begin{array}{l}\text { CDAI, IBDQ, nutritional status, } \\
\text { micronutrient levels, CRP and } \\
\text { body composition among } \\
\text { others were measured. }\end{array}$ & $\begin{array}{l}\text { EPA }>2 \% \text { group increased the BMI, fat mass, fat-free mass, IBDQ }(+41.4 \\
[23.1,47.0] ; p=0.002) \text { and the CDAI decreased }(-47.8[-65,-37.8] ; p=0.05) \\
\text { There were no differences between groups for the rest of the variables } \\
\text { studied. }\end{array}$ \\
\hline
\end{tabular}


Table 1. Cont

\begin{tabular}{|c|c|c|c|c|c|c|c|c|}
\hline Author & Study & $n /$ age & Disease & $\mathrm{P} / \mathrm{d}$ & $\mathrm{CC}$ & Treatment & Variables & Main Results \\
\hline $\begin{array}{l}\text { Takayuki } \\
\text { Yamamoto et al. } \\
2010[26]\end{array}$ & NRCCT & $\begin{array}{l}56 / 32 \\
\text { M } 36 \\
\text { F } 20\end{array}$ & $\begin{array}{l}\text { REM } \\
\text { CD } \\
\text { EG/CG } \\
32 / 24\end{array}$ & 392 & $\mathrm{JP}$ & $\begin{array}{l}\text { EG. Elemental formula } \\
\text { "Elental" by nasogastric tube at } \\
\text { night and low-fat foods during } \\
\text { the day. } \\
\text { CG. Unrestricted Diet }\end{array}$ & $\begin{array}{l}\text { WBC, HB, hematocrit, platelet } \\
\text { count, ESR, CRP and albumin. } \\
\text { CDAI. Symptoms, adverse } \\
\text { effects, stool parameters. }\end{array}$ & $\begin{array}{l}\text { The CDAI did not decrease significantly. No differences were observed } \\
\text { between the groups. }(p=0.51) \text {. The cumulative proportion of patients in } \\
\text { clinical remission was not significantly different between the groups. }\end{array}$ \\
\hline $\begin{array}{l}\text { Takayuki } \\
\text { Yamamoto et al. } \\
2006[27]\end{array}$ & NRCCT & $\begin{array}{l}40 / 32 \\
\text { M } 26 \\
\text { F } 14\end{array}$ & $\begin{array}{l}\mathrm{ACT} \\
\mathrm{CD} \\
\mathrm{EG} / \mathrm{CG} \\
20 / 20\end{array}$ & +365 & $J P$ & $\begin{array}{l}\text { EG: Elemental formula } \\
\text { "Elental" by nasogastric tube at } \\
\text { night and low-fat foods during } \\
\text { the day. } \\
\text { CG. Unrestricted Diet }\end{array}$ & $\begin{array}{l}\text { WBC, HB, platelet count, ESR, } \\
\text { CRP and albumin. CDAI and } \\
\text { parameters by ileocolonoscopy. }\end{array}$ & $\begin{array}{l}\text { During the year of follow-up, } 1 \text { patient of the EG and } 7 \text { in the CG developed } \\
\text { clinical recurrence }(p=0.048) \text {. At } 6 \text { months, } 5 \text { patients of the EG and } 8 \text { of the } \\
\text { CG developed endoscopic recurrence (odds ratio, } 2.0 ; p=0.50 \text { ). At } 12 \\
\text { months, } 6 \text { patients from the EG and } 14 \text { from the CG showed endoscopic } \\
\text { recurrence (odds ratio, } 5.4 ; p=0.027 \text { ) }\end{array}$ \\
\hline S. Takagi et al. 2006 [28] & RCCT & $\begin{array}{l}51 / 30 \\
\text { M } 37 \\
\text { F } 14\end{array}$ & $\begin{array}{l}\text { REM } \\
\text { CD } \\
\text { EG/CG } \\
26 / 25\end{array}$ & 730 & $J P$ & $\begin{array}{l}\text { EG: Half of calories, elementary } \\
\text { diet through a enteral or oral } \\
\text { intake and the remaining half } \\
\text { by regular meals. } \\
\text { CG: Unrestricted Diet }\end{array}$ & $\begin{array}{l}\text { CDAI. Parameters of: feces, } \\
\text { symptoms and laboratory tests. }\end{array}$ & $\begin{array}{l}\text { After an average follow-up of } 11.9 \text { months, the relapse rate in the EG was } \\
\text { significantly lower than in the CG [34.6\% vs. } 64.0 \% \text {; Multivariate risk ratio } \\
0.40(95 \% \text { CI: } 0.16-0.98)] \text {. No significant changes on the rest of the variables }\end{array}$ \\
\hline $\begin{array}{l}\text { Tadao Bamba et al. } \\
2003 \text { [29] }\end{array}$ & RCCT & $\begin{array}{l}28 / 28 \\
\text { M } 17 \\
\text { F } 11\end{array}$ & $\begin{array}{l}\text { ACT } \\
\text { CD } \\
\text { Low/ } \\
\text { Medium/ } \\
\text { High Fat EN } \\
\text { 10/10/8 }\end{array}$ & 28 & $J P$ & $\begin{array}{l}\text { LOWG: } 6 \text { packages of } \\
\text { elemental diet "Elental" and } 6 \\
\text { packages of dextrin } \\
\text { MEDG: } 6 \text { packages of } \\
\text { elemental diet "Elemental", } 3 \\
\text { packages of dextrin and } 3 \\
\text { packages of dextrin C-1 } \\
\text { (dextrin + soybean oil). } \\
\text { HIGHG: } 6 \text { packages of } \\
\text { elemental diet "Elemental" and } \\
6 \text { packages of dextrin C-1. } \\
\text { Administration: Nasogastric } \\
\text { tube. }\end{array}$ & $\begin{array}{l}\text { IOIBD, inflammatory markers } \\
\text { (CRP, ESR) and body weight } \\
\text { were recorded at each } \\
\text { follow-up. }\end{array}$ & $\begin{array}{l}\text { No differences in body weight gains. The LOWG's IOIBD was significantly } \\
\text { higher than in the MEDG and HIGHG groups }(p=0.048) \text { and the CRP lower } \\
\text { after the first week. } \\
\text { In the MEDG and HIGHG groups the CRP fluctuated during the study. In } \\
\text { the LOWG group the ESR decreased, but for the other groups they } \\
\text { remained high or increased during the study. } \\
\text { Clinical remission was achieved in } 8,4 \text { and } 2 \text { patients in the LOWG, MEDG } \\
\text { and HIGHG groups respectively. This remission rate is significant if } \\
\text { grouped in LOWG vs. MEDG \& HIGHG }(p=0.046) \text {. }\end{array}$ \\
\hline $\begin{array}{l}\text { M A Gassull et al. } \\
2002[30]\end{array}$ & RCCT & $\begin{array}{l}62 / 29 \\
\text { M } 24 \\
\text { F } 29\end{array}$ & $\begin{array}{c}\text { ACT } \\
\text { CD } \\
\text { PEN1/PEN2/ESTG } \\
\text { 20/23/19 }\end{array}$ & 28 & $\begin{array}{l}\text { ES } \\
\text { GB } \\
\text { DE }\end{array}$ & $\begin{array}{l}\text { PEN 1: Polymeric EN, rich in } \\
\text { n9 monounsaturated fatty } \\
\text { acids (MUFA) (oleic acid). } \\
\text { PEN 2: Polymeric EN rich in } \\
\text { n6 polyunsaturated fatty acids } \\
\text { (PUFA) (linoleic acid) } \\
\text { ESTG (Steroid group): } \\
\text { Prednisone. }\end{array}$ & $\begin{array}{l}\text { ESR, CRP, serum fibrinogen, } \\
\text { VHAI, CDAI, NRI, serum } \\
\text { albumin and grip strength }\end{array}$ & $\begin{array}{l}\text { The intention-to-treat analysis showed that the remission rates were } 20 \% \text {, } \\
52 \% \text { and } 79 \% \text { for PEN P1, PEN2 and ESTG }(p=0.001) \text {. Withdrawal from } \\
\text { treatment, remission rates were } 27 \%, 63 \% \text { and } 79 \% \text {, respectively }(p=0.008) \text {. } \\
\text { No differences in remission time and changes in activity rates, inflammatory } \\
\text { biological parameters, NRIs and nutritional variables. }\end{array}$ \\
\hline
\end{tabular}


Table 1. Cont

\begin{tabular}{|c|c|c|c|c|c|c|c|c|}
\hline Author & Study & $n /$ age & Disease & $\mathrm{P} / \mathrm{d}$ & $\mathrm{CC}$ & Treatment & Variables & Main Results \\
\hline $\begin{array}{l}\text { Toshihiro Sakurai et al. } \\
2002 \text { [31] }\end{array}$ & RCCT & $\begin{array}{l}36 / 26 \\
\text { M } 30 \\
\text { F } 6\end{array}$ & $\begin{array}{c}\mathrm{ACT} \\
\mathrm{CD}=36 \\
\mathrm{EDG} / \mathrm{TLG} \\
18 / 18\end{array}$ & 42 & $\mathrm{JP}$ & $\begin{array}{l}\text { EDG: “Elental” Formula } \\
\text { (Ajinomoto Pharma) low in fat. } \\
\text { TLG: Twinline Formula } \\
\text { (Otsuka Pharma) large amount } \\
\text { of medium chain triglycerides } \\
\text { Administration: Tube in the } \\
\text { duodenum. }\end{array}$ & $\begin{array}{l}\text { CDAI, VHAI, CRP, ESR, levels } \\
\text { of: serum albumin, plasma } \\
\text { prealbumin, plasma transferrin } \\
\text { and retinol binding protein in } \\
\text { plasma and triene/tetraeno } \\
\text { ratio. }\end{array}$ & $\begin{array}{l}\text { After } 2 \text { weeks, serum levels of linoleic acid, an omega } 6 \text { fatty acid, decreased } \\
\text { significantly in the EDG group. Without significant differences was } \\
\text { observed: a short-term remission in } 67 \% \text { in the EDG and } 72 \% \text { in the TLG, a } \\
\text { reduction in the CDAI and the VHAI, a normalization of the CRP and an } \\
\text { improvement in the ESR and levels serum; albumin, plasma prealbumin, } \\
\text { plasma transferrin and plasma retinol binding protein, the linolenic acid } \\
\text { levels decreased in both groups. }\end{array}$ \\
\hline S. Verma et al. 2000 [32] & NRCCT & $\begin{array}{l}39 / 40 \\
\text { M } 12 \\
\text { F } 27\end{array}$ & $\begin{array}{l}\text { REM } \\
\text { CD } \\
\text { EG/CG } \\
21 / 28\end{array}$ & 365 & GB & $\begin{array}{l}\text { EG: Oral nutritional } \\
\text { supplementation with } \\
\text { elemental diet "EO28 Extra", } \\
\text { plus normal diet. } \\
\text { CG: Unrestricted Diet. }\end{array}$ & $\begin{array}{l}\text { CDAI, inflammatory markers } \\
\text { such as CRP, ESR, albumin, } \mathrm{HB} \\
\text { and platelet count. }\end{array}$ & $\begin{array}{l}\text { The intention-to-treat analysis showed that the remission rates were } 48 \% \\
\text { and } 22 \% \text { for EG AND CG }(p=0.0003) \text {. Withdrawal from treatment, } \\
\text { remission rates were } 60 \% \text {, and } 22 \% \text {, respectively }(p<0.00001) \text {. Without } \\
\text { showing significant differences were observed: a stability of the levels of } \\
\text { CDAI and albumin and an increase in BMI. A significant decrease in ESR } \\
\text { was observed }\end{array}$ \\
\hline Verma S et al. 2000 [33] & RCCT & $\begin{array}{l}21 / 35 \\
\text { M } 8 \\
\text { F } 13\end{array}$ & $\begin{array}{l}\text { ACT } \\
\text { CD } \\
\text { GA/GP } \\
11 / 10\end{array}$ & 28 & UK & $\begin{array}{l}\text { GA: Free amino acids diet. } \\
\text { GP: Polymeric diet. } \\
\text { Administration: nasogastric } \\
\text { tube. Water was allowed. }\end{array}$ & $\begin{array}{l}\text { CDAI, inflammatory markers } \\
\text { (CRP, etc.), BMI and body } \\
\text { weight. }\end{array}$ & $\begin{array}{l}\text { Clinical remission was achieved in } 8(80 \%) \text { and } 6(55 \%) \text { patients in the GA } \\
\text { and GP groups, respectively (without significant differences, } p=0.1) \text {. In } \\
\text { both groups CDAI (GA, } 359 \pm 67 \text { to } 112 \pm 19, p \leq 0.0002 ; \mathrm{GP}, 303 \pm 27 \text { to } 97 \pm \\
11, p \leq 0.0005 \text { ) and CRP (GA, } 16 \pm 5 \text { to } 4 \pm 1.6, p<0.1 ; \mathrm{GP}, 62 \pm 20 \text { to } 9 \pm 6, \\
p<0.04) \text { decreased. Remission was achieved earlier in GA (7) } 7 \text { days) than } \\
\text { in GP (14 } \pm 2 \text { days) (without significant differences). Overall, enteral } \\
\text { feeding was successful in } 14 \text { patients ( } 63 \% \text { ). }\end{array}$ \\
\hline $\begin{array}{l}\text { Bruno Schneeweiss et al. } \\
1999[34]\end{array}$ & NRCCT & $\begin{array}{l}26 / 28 \\
\text { M } 9 \\
\text { F } 17\end{array}$ & $\begin{array}{c}\text { ACT } \\
\text { CD } \\
\text { EG/CG } \\
7 / 19 \\
\end{array}$ & 15 & AT & $\begin{array}{l}\text { EG: } 7 \text { patients received enteral } \\
\text { nutrition by nasogastric tube }\end{array}$ & $\begin{array}{l}\text { Energy expenditure, UNP, } \\
\text { changes in the body's urea } \\
\text { nitrogen set and body } \\
\text { composition. }\end{array}$ & $\begin{array}{l}\text { The REE did not change. From day } 7 \text { the UNP, RQ and RQ without proteins } \\
\text { increased significantly. These changes (except carbohydrate oxidation rates) } \\
\text { were reversed when the EN was interrupted. }\end{array}$ \\
\hline $\begin{array}{l}\text { Dawna Royall et al. } \\
1995 \text { [35] }\end{array}$ & NRCCT & $\begin{array}{l}60 / 30 \\
\text { M } 32 \\
\text { F } 28\end{array}$ & $\begin{array}{l}\text { ACT } \\
\text { CD } \\
\text { EG/CG } \\
30 / 30\end{array}$ & 21 & $\mathrm{CA}$ & $\begin{array}{l}\text { EG: one of two elementary } \\
\text { diets, Peptamen or } \\
\text { Vivonex-TEN, administered by } \\
\text { nasoduodenal tube. }\end{array}$ & $\begin{array}{l}\text { Total body protein, fat, water } \\
\text { and body potassium. }\end{array}$ & $\begin{array}{l}\text { Compared to the CG, the EG lost } 11.3 \mathrm{~kg}(p<0.0005),(5.1 \mathrm{~kg} \text { fat }(p<0.0005) \text {, } \\
2.2 \mathrm{~kg} \text { protein }(p<0.025), 3.7 \mathrm{~kg} \text { water, } 24.9 \mathrm{~g} \text { body potassium }(p<0.01)) \text {. } \\
\text { After EN, body weight }(1.9 \pm 0.3 \mathrm{~kg} ; p<0.0005), \text { body protein }(0.3 \pm 0.1 \mathrm{~kg} \text {; } \\
p<0.025) \text {, fat }(0.3 \pm 0.1 \mathrm{~kg} ; p<0.025) \text { and water }(1.1 \pm \text { more; } 0.4 \mathrm{~kg} ; p<0.025) \\
\text { was significantly increased. Body potassium increased but not significantly. }\end{array}$ \\
\hline $\begin{array}{l}\text { Mansfield JC et al. } \\
1995 \text { [36] }\end{array}$ & RCCT & $\begin{array}{l}44 /- \\
\text { M } 16 \\
\text { F } 28\end{array}$ & $\begin{array}{l}\mathrm{ACT} \\
\mathrm{CD} \\
\mathrm{GA} / \mathrm{GP} \\
22 / 22\end{array}$ & 28 & GB & $\begin{array}{l}\text { GA: Enteral formula based on } \\
\text { amino acids "Elemental 028". } \\
\text { GP: Enteral formula based on } \\
\text { oligopeptide-based diet } \\
\text { "Pepti-2000 LF liquid". Water } \\
\text { was allowed. }\end{array}$ & $\begin{array}{l}\text { CDAI, laboratory activity } \\
\text { measures (HB, platelet count, } \\
\text { ESR, serum albumin } \\
\text { concentration, AAGP and CRP) } \\
\text { and body weight. }\end{array}$ & $\begin{array}{l}16 \text { patients }(36.4 \%) \text { achieved clinical remission and decreased CRP }(p=0.05) \text {. } \\
\text { Both groups had identical rates of remission, failure, early withdrawal and } \\
\text { nasogastric feeding intolerance. There was an increase in serum albumin in } \\
\text { patients who started the study at a low level. }\end{array}$ \\
\hline $\begin{array}{l}\text { Teahon K et al. } \\
1995[37]\end{array}$ & UNRCT & $\begin{array}{l}19 / 37 \\
\text { M } 10 \\
\text { F } 9\end{array}$ & $\begin{array}{l}\mathrm{ACT} \\
\mathrm{CD}\end{array}$ & 35 & GB & $\begin{array}{l}\text { Elemental diet "Vivonex" was } \\
\text { using in one group }(n=8) \text { and } \\
\text { "Elemental } 028 \text { " in the other } \\
(n=11) \text {, by oral route. }\end{array}$ & $\begin{array}{l}\text { CDAS, biochemical parameters } \\
\text { (HB, platelet count, leukocytes, } \\
\text { ESR, iron, magnesium, copper, } \\
\text { zinc ... ), fecal parameters, } \\
\text { BMI and body composition. }\end{array}$ & $\begin{array}{l}\text { Changes were similar in both groups. Clinical disease activity and fecal } \\
\text { excretion of leukocytes were significantly reduced after } 2 \text { weeks of } \\
\text { treatment. Transferrin, prealbumin, albumin and serum iron were } \\
\text { significantly increased at } 4 \text { weeks. Serum copper decreased during the } \\
\text { study period. Changes in nutrition measures did not correlate significantly } \\
\text { with changes in disease activity. }\end{array}$ \\
\hline
\end{tabular}


Table 1. Cont

\begin{tabular}{|c|c|c|c|c|c|c|c|c|}
\hline Author & Study & $n /$ age & Disease & $\mathrm{P} / \mathrm{d}$ & $\mathrm{CC}$ & Treatment & Variables & Main Results \\
\hline $\begin{array}{l}\text { M.F.J. Stolk et al. } \\
1994[38]\end{array}$ & UNRCT & $\begin{array}{l}6 / 27 \\
\text { M } 3 \\
\text { F } 3\end{array}$ & $\mathrm{CD}$ & 42 & NL & $\begin{array}{l}\text { By using a pump, the formula } \\
\text { "Peptison" (Nutricia) was } \\
\text { supplied. }\end{array}$ & $\begin{array}{l}\text { Volume, motility, emptying } \\
\text { and filling variables of the } \\
\text { gallbladder were calculated, } \\
\text { and concentration of CCK in } \\
\text { the plasma }\end{array}$ & $\begin{array}{l}\text { At the start of treatment, the fasting gallbladder volume decreased from } \\
19.3+/-4.5 \text { to } 4.9+/-3.6 \mathrm{~mL} \text {. The CCK increased from } 1.5+/-0.3 \text { to } 3.9+- \\
1.1 \text { pmol/L. After } 8 \text { days, the gallbladder contracted almost completely, the } \\
\text { CCK increased to } 7.5+/-2.7 \text {, and at } 36 \text { days, CCK increased to } 8.3+/-2.6 \\
\text { pmol/L. After } 22 \text { days } 22 \text { the volume of the gallbladder increased, and after } \\
46 \text { the CCK decreased. This change was significantly greater than the CCK } \\
\text { change on day } 1(p<0.05)\end{array}$ \\
\hline D Royall et al. 1994 [39] & RCCT & $\begin{array}{l}40 / 31 \\
\text { M } 23 \\
\text { F } 17\end{array}$ & $\begin{array}{l}\text { ACT } \\
\text { CD } \\
\text { AG/PG } \\
19 / 21\end{array}$ & 21 & CA & $\begin{array}{l}\text { AG: Enteral formula based on } \\
\text { amino acids "Vivonex-TEN". } \\
\text { PG: Enteral formula based on } \\
\text { peptides "Peptamen". } \\
\text { Administered by nasogastric } \\
\text { tube. Water was allowed. }\end{array}$ & $\begin{array}{l}\text { CDAI, CRP, AAGP, } \\
\text { phospholipids, albumin and } \\
\text { transferrin. Body weight and } \\
\text { total body nitrogen was } \\
\text { evaluated. }\end{array}$ & $\begin{array}{l}\text { After } 21 \text { days, remission rates were equivalent between the two groups: } \\
84 \% \text { for the AG and } 75 \% \text { for the PG }(p=0.38) \text {. At } 12 \text { months, it remained at } \\
31 \% \text { and } 40 \% \text { respectively }(p=0.39) \text {. } \\
\text { Also, the reductions of CDAI, AAGP and CRP were significant. Linoleic } \\
\text { acid decreased and total body nitrogen increased significantly in AG but not } \\
\text { in PG }(p<0.025) \text {. The concentration of phospholipids in plasma increased } \\
\text { significantly in the PG }\end{array}$ \\
\hline $\begin{array}{l}\text { F González-Huix et al. } \\
1993 \text { [40] }\end{array}$ & RCCT & $\begin{array}{l}32 / 31 \\
\text { M } 17 \\
\text { F15 }\end{array}$ & $\begin{array}{l}\text { ACT } \\
\text { CD } \\
\text { PENG/ESTG } \\
15 / 17\end{array}$ & 28 & ES & $\begin{array}{l}\text { PENG: The polymeric EN } \\
\text { administered by nasogastric } \\
\text { tube. } \\
\text { ESTG: Prednisone } \\
\text { administration. And diet } \\
\text { lactose-free while they were in } \\
\text { the hospital. }\end{array}$ & $\begin{array}{l}\text { VHAI, CRP. Evaluation of body } \\
\text { weight, \% IBW, MAMC, TSF, } \\
\text { serum albumin concentration. } \\
\text { Complete hematological and } \\
\text { biochemical analysis. }\end{array}$ & $\begin{array}{l}\text { There were no significant differences in the mean time }(p=0.47) \text { and the } \\
\text { number of patients who obtained clinical remission }(p=0.43) \text {. The VHAI } \\
\text { decreased in both groups; PENG from } 172.5 \text { to } 113.8,(p=0.0001) \text {, ESTG } \\
\text { from } 184.3 \text { to } 118.1,(p=0.0003) \text {. In both groups the CRP decreased and the } \\
\text { serum albumin concentration increased significantly. After one year, } 10 \\
\text { patients }(66.6 \%) \text { in the ESTG and } 5(41.6 \%) \text { in the PENG relapsed. No } \\
\text { differences in the cumulative probability of relapse. }\end{array}$ \\
\hline $\begin{array}{l}\text { Hiroyuki } \\
\text { Hirakawa et al. } \\
1993 \text { [41] }\end{array}$ & NRCCT & $\begin{array}{l}61 / 25 \\
\text { M } 39 \\
\text { F } 22\end{array}$ & $\begin{array}{c}\text { REM } \\
\text { CD } \\
\text { ENG/ENG+D/DG/CC } \\
25 / 22 / 8 / 6\end{array}$ & & $J P$ & $\begin{array}{l}\text { ENG: Elemental EN (“Elental”) } \\
\text { through nasoenteral tube. } \\
\text { ENG+D: } \frac{1}{2} \text { ENG }+\frac{1}{2} \text { Low-fat } \\
\text { diet and prednisolone } \\
\text { DG: Low-fat diet and } \\
\text { prednisolone CG: Unrestricted } \\
\text { Diet }\end{array}$ & IOIBD, ESR and CRP & $\begin{array}{l}\text { The cumulative rates of continuous remission after } 1,2 \text { and } 4 \text { years were in } \\
\text { the ENG } 94 \%, 63 \% \text { and } 63 \% \text {; in the ENG }+\mathrm{D} 75 \%, 66 \% \text { and } 66 \% \text { in the DG } \\
63 \% ; 42 \% \text { and } 0 \% \text {, and in the CG } 50 \%, 33 \% \text {. and } 0 \% \text {. The ENG had a higher } \\
\text { rate than DG }(p<0.05) \text { and CG }(p<0.01) \text {. The ENG }+ \text { D had a higher rate } \\
\text { than the CG }(p<0.05) \text {. Patients who received more than } 30 \text { kcal of EN } \\
\text { showed a higher continuous remission rate }(p<0.001) \text {. }\end{array}$ \\
\hline $\begin{array}{l}\text { D Rigaud et al. } \\
1991 \text { [42] }\end{array}$ & RCCT & $\begin{array}{l}30 / 35 \\
\text { M } 18 \\
\text { F } 12\end{array}$ & $\begin{array}{l}\text { ACT } \\
\text { CD } \\
\text { EENG/PENG } \\
15 / 15\end{array}$ & 28 & FR & $\begin{array}{l}\text { EENG: Elementary enteral } \\
\text { formula "Vivonex HN" } \\
\text { PENG: "Realmentyl" } \\
\text { polymeric formula }\end{array}$ & $\begin{array}{l}\text { CDAI, fecal production, } \\
\text { colonoscopies. Body weight; } \\
\text { TSF, MAMC, daily urinary, } \\
\text { creatinine-height ratio; blood } \\
\text { levels of HB, albumin and } \\
\text { transferrin. ESR, } \alpha 2 \text { globulin } \\
\text { level and WBC counts. }\end{array}$ & $\begin{array}{l}\text { The clinical remission was in the EENG of } 66 \% \text { and in the PENG of } 73 \% \text {. } \\
\text { The CDAI and ESR levels were significantly reduced in both groups. } \\
\text { There were no differences between groups for inflammatory markers, } \\
\text { colonoscopic lesions, fecal production, body weight and creatinine index. }\end{array}$ \\
\hline $\begin{array}{l}\text { Herbert Lochs et al. } \\
1991 \text { [43] }\end{array}$ & RCCT & $\begin{array}{l}107 / 29 \\
\text { M } 37 \\
\text { F } 70\end{array}$ & $\begin{array}{l}\text { ACT } \\
\text { CD } \\
\text { OENG/CSG } \\
55 / 52\end{array}$ & 42 & $\mathrm{DE}$ & $\begin{array}{l}\text { OENG: Enteral nutrition by } \\
\text { oligopetidic formula } \\
\text { "Peptisorb" through } \\
\text { nasogastric or nasoduodenal } \\
\text { tube. More tea or water. } \\
\text { CSG: Combination of } \\
\text { corticosteroids and } \\
\text { sulfasalazine. }\end{array}$ & CDAI and laboratory tests. & $\begin{array}{l}\text { After } 6 \text { weeks, } 29 \text { patients achieved remission in the OENG and } 41 \text { patients } \\
\text { in the CSG }(p<0.01) \text {. The remission time was significantly different } \\
(p<0.01) \text {. A CDAI below } 150 \text { was achieved in the OENG in } 24 \text { patients and } \\
\text { in the CSG in } 35 \text {. The CDAI and severe malnutrition parameters showed no } \\
\text { significant differences in patients in remission. }\end{array}$ \\
\hline
\end{tabular}


Table 1. Cont

\begin{tabular}{|c|c|c|c|c|c|c|c|c|}
\hline Author & Study & $n /$ age & Disease & $\mathrm{P} / \mathrm{d}$ & $\mathrm{CC}$ & Treatment & Variables & Main Results \\
\hline $\begin{array}{l}\text { A.H. Raouf et al. } \\
1991[44]\end{array}$ & RCCT & $24 /-$ & $\begin{array}{c}\text { ACT } \\
\text { CD } \\
\text { EENG/PENG } \\
13 / 11\end{array}$ & 21 & GB & $\begin{array}{l}\text { EENG: Enteral amino } \\
\text { acid-based food "EO28" } \\
\text { PENG: Whole protein-based } \\
\text { whole food "Triosrbon". } \\
\text { Administration: Oral, flavored } \\
\text { with Nesquick. }\end{array}$ & $\begin{array}{l}\text { ESR, erythrocytes, VHAI, Bristol } \\
\text { simple activity index and the CRP. }\end{array}$ & $\begin{array}{l}\text { After } 3 \text { weeks, they reached remission in the EENG } 9 \text { patients and in the } \\
\text { PENG } 8 \text { patients }(p<0.01) \text {. The Bristol simple activity index improved in } \\
\text { the two groups (EENG; } 91.7 \% \text {, PENG; } 86.7 \%(p=0.35)) \text {, Similarly; VHAI } \\
\text { (EENG; } 18.5 \% \text {, PENG; } 30.0 \% \text {, }(p=0.23)) \text {, and CRP (EENG; } 58.3 \% \text {, PENG; } \\
57.1 \%,(p=0.49)) \text {. }\end{array}$ \\
\hline $\begin{array}{l}\text { Richard A. Wright et al. } \\
1990 \text { [45] }\end{array}$ & RCCT & $\begin{array}{l}11 /- \\
\text { M } 7 \\
\text { F } 4\end{array}$ & $\begin{array}{c}\text { ACT } \\
\text { CD } \\
\text { EENG/PNG } \\
6 / 5 \\
\end{array}$ & 14 & US & $\begin{array}{l}\text { EENG: Elemental enteral } \\
\text { feeding "Vital" } \\
\text { PNG: Determined peripheral } \\
\text { parenteral nutrition. }\end{array}$ & $\begin{array}{l}\text { CDAI, standard anthropometric } \\
\text { parameters, nitrogen balance } \\
\text { studies and chemical profiles. }\end{array}$ & $\begin{array}{l}\text { CDAI improved significantly in both groups. Plasma transferrin levels and } \\
\text { total lymphocyte count improved in the EENG group }(p<0.05) \text {. No } \\
\text { significant differences in weight gain. }\end{array}$ \\
\hline $\begin{array}{l}\text { Giaffer MH et al. } \\
1990[46]\end{array}$ & RCCT & $\begin{array}{l}30 / 38 \\
\text { M } 8 \\
\text { F } 22\end{array}$ & $\begin{array}{l}\mathrm{ACT} \\
\mathrm{CD} \\
\mathrm{AG} / \mathrm{PG} \\
16 / 14\end{array}$ & 28 & UK & $\begin{array}{l}\text { AG: Amino acid diet } \\
\text { "Vivonex". } \\
\text { PG: Polymeric diet "Fortison". } \\
\text { Administration: nasogastric } \\
\text { tube. Water was allowed. }\end{array}$ & $\begin{array}{l}\text { CDAI, total body weight, MAMC, } \\
\text { TSF and biochemical } \\
\text { measurements such as serum } \\
\text { albumin. }\end{array}$ & $\begin{array}{l}12(75 \%) \text { AG patients achieved remission at } 10 \text { days, compared with } 5 \\
(35.8 \%) \text { in the PG group }(p=0.03) \text {. CDAI decreased significantly in the AG } \\
\text { group, not the PG group. The mean weight gain in both groups was similar. } \\
\text { Mean serum albumin increased from } 26 \mathrm{~g} / \mathrm{L} \text { to } 33 \mathrm{~g} / \mathrm{L}(p<0.001) \text {. Also, there } \\
\text { were significant changes in ESR and AAGP in both groups. }\end{array}$ \\
\hline $\begin{array}{l}\text { Abad-Lacruz A et al. } \\
1990[47]\end{array}$ & RCCT & $\begin{array}{l}22 / 32 \\
\text { M } 15 \\
\text { F } 14\end{array}$ & $\begin{array}{c}\text { ACT } \\
\text { IBD } \\
\text { PG/TPNG } \\
16 / 13\end{array}$ & NI & ES & $\begin{array}{l}\text { PG: Polymeric diet high in } \\
\text { nitrogen "UNIASA" by } \\
\text { nasogastric tube. } \\
\text { TPNG: Specific total parenteral } \\
\text { nutrition by a central vein. }\end{array}$ & $\begin{array}{l}\text { Biochemical measurements (total } \\
\text { serum bilirubin, alkaline } \\
\text { phosphatase, GGT, ALT, and AST) } \\
\text { and VHAI and the Truelove and } \\
\text { Witts index were measured. }\end{array}$ & $\begin{array}{l}\text { PG had a significant increase in serum albumin concentration }(32 \pm 1 \text { to } 38.2 \\
\pm 1.6 \mathrm{~g} / \mathrm{L} ; p<0.01) \text {. There was lower disease activity in both groups }(3.31 \pm \\
0.15 \text { to } 2.31 \pm 0.24, p<0.05 \text { in GP; and } 3.38 \pm 0.21 \text { to } 2.61 \pm 0.27, p<0.05 \text { in } \\
\text { TPNG). } 8 \text { ( } 5 \mathrm{CD} \text { and } 3 \mathrm{UC}) \text { of } 13 \text { patients }(61.5 \%) \text { in the TPNG group } \\
\text { developed abnormalities in LFT, while in the PG group only occurred in } 1 \text { of } \\
16 \text { patients }(6.2 \%)(p=0.002) \text {. }\end{array}$ \\
\hline $\begin{array}{l}\text { Greenberg GR et al. } \\
1988[48]\end{array}$ & RCCT & $\begin{array}{l}51 / 30 \\
\text { M } 25 \\
\text { F } 26\end{array}$ & $\begin{array}{c}\text { ACT } \\
\text { CD } \\
\text { TPNG/ENG/PPNG } \\
17 / 19 / 15\end{array}$ & 21 & $\mathrm{CA}$ & $\begin{array}{l}\text { TPNG: Total parenteral } \\
\text { nutrition, more water, plus } \\
\text { daily one ampoule of vitamins. } \\
\text { ENG: formula diet } \\
\text { "Precision-Isotonic". } \\
\text { PPNG: Unrestricted diet and a } \\
\text { partial protein/calorie } \\
\text { parenteral nutrition. }\end{array}$ & $\begin{array}{l}\text { CDAI, nutritional assessment and } \\
\text { biochemical measurements } \\
\text { (hematocrit, blood glucose, serum } \\
\text { electrolytes, creatinine, } \\
\text { magnesium and albumin). }\end{array}$ & $\begin{array}{l}\text { The average CDAI decreased }(p<0.01) \text { with no significant differences } \\
\text { between groups. Remission rates to discharge were equivalent among the } \\
\text { three groups: } 12 \text { patients in TPNG, } 11 \text { patients in ENG and } 9 \text { patients in } \\
\text { PPNG and oral diet }(X 21.42 \text { and } 1.15 ; p=\mathrm{n} / \mathrm{s}) \text {. Remission rates of } 42 \% \text { in } \\
\text { TPNG, } 55 \% \text { in EN and } 56 \% \text { in PPNG at } 12 \text { months were equivalent and not } \\
\text { influenced by the type of nutritional support initially administered. At } 12 \\
\text { months, } 18 \text { patients }(35 \%) \text { required surgery, } 17(34 \%) \text { were medically treated } \\
\text { for relapse, and } 16(31 \%) \text { had sustained remission. }\end{array}$ \\
\hline $\begin{array}{l}\text { Harries AD et al. } \\
1983[49]\end{array}$ & RCCT & $\begin{array}{l}28 / 37 \\
\text { M } 17 \\
\text { F } 11\end{array}$ & $\begin{array}{l}\mathrm{ACT} \\
\mathrm{CD} \\
\mathrm{G} 1 / \mathrm{G} 2 \\
14 / 14\end{array}$ & 120 & GB & $\begin{array}{l}\text { G1: } 2 \text { months ordinary diet } \\
\text { followed by } 2 \text { months } \\
\text { supplementation with the } \\
\text { non-elememtary low-waste } \\
\text { formula "Guarantee Plus". } \\
\text { G2: same intervention than G1 } \\
\text { with invested order. }\end{array}$ & $\begin{array}{l}\text { Nutritional measurements (height, } \\
\text { weight, MAMC and thickness of } \\
\text { the skin fold), biochemical } \\
\text { measurements (serum prealbumin, } \\
\text { serum, red cell folate, creatinine } \\
\text { height index, platelets, T } \\
\text { lymphocytes, etc.) and urine tests } \\
\text { parameters. }\end{array}$ & $\begin{array}{l}\text { The general effect of EN during the } 2 \text { months was to increase serum } \\
\text { albumin, serum protein and prealbumin levels, creatinine height index and } \\
\text { T-lymphocyte count. With EN decreased levels of orosomucoids and serum } \\
\text { alkaline phosphatase and its activity }(p<0.05) \\
\text { Patients felt better when they received EN, although their monthly } \\
\text { symptom scores showed no significant benefit. }\end{array}$ \\
\hline
\end{tabular}

P/d: Period (days); CC: ISO country codes; UNRCT: Uncontrolled and non-randomized clinical trial; NRCCT: Non-randomized controlled clinical trials; RCCT: Randomized controlled clinical trials; UCT: Uncontrolled clinical trial; IBD: Inflammatory bowel disease; EG/CG: Experimental and Control Group; UC: Ulcerative colitis; EN: Enteral nutrition; CD: Crohn's disease; ACT: Active disease; REM: Disease in remission; M: Male; F: Female; CDAI: Crohn's disease activity index; VHAI: Van Hees activity index; CRP: C-reactive protein; ESR: erythrocyte sedimentation rate; BMI: Body mass index; HBI: Harvey-Bradshaw Index, SCFA: Short chain fatty acid, SGA: Subjective global assessment; WBC: White blood cells, CT: computed tomography exam, HB: Hemoglobin; IBDQ: Inflammatory bowel disease questionnaire; IOIBD: International Organization of Inflammatory Bowel Disease rating; NRI: Nutritional risk index; UNP: Urea Nitrogen appearance rate; RQ: Respiratory quotients; REE: resting energy expenditure; CCK: Cholecystokinin; AAGP: Alpha-1 acid glycoprotein; \%IBW: Percentage of ideal body weight; MAMC: Mid-arm muscle circumference; TSF: Triceps skinfold thickness; HEEH: Home elemental enteral hyperalimentation; GGT: $\gamma$-glutamyltransferase; ALT: Alanine aminotransferase; AST: Aspartate aminotransferase; LFT: Liver function test; TNF: Tumor necrosis factor; IL: Interleukin; htMAT: hypertrophied messenteric adipose tissue; PTH: Parathyroid hormone; IBDNF: Inflammatory bowel disease nutrition formula; EPA: eicosapentaenoic acid; CDAS: Crohn's disease activity score. 


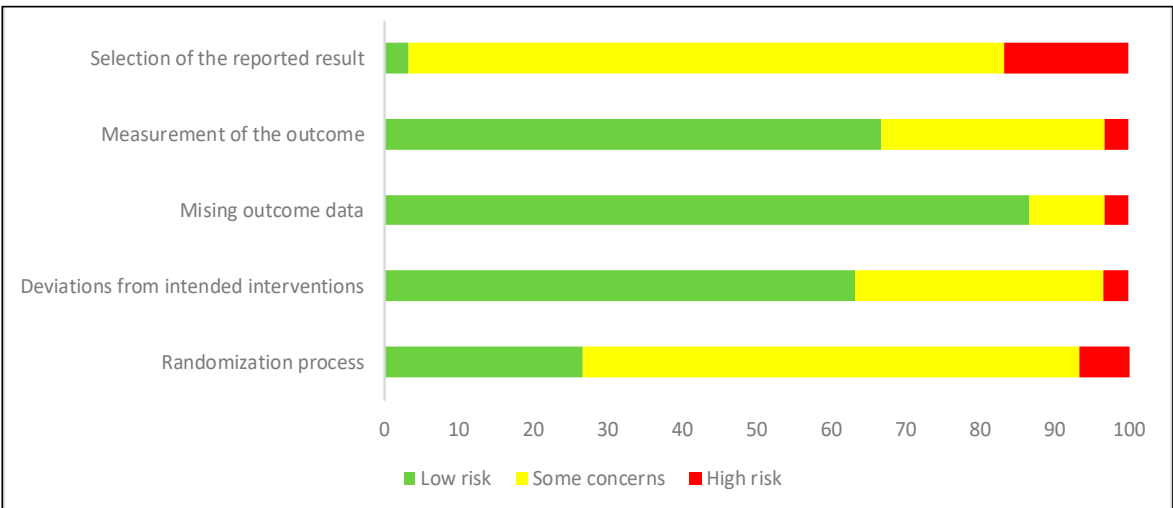

Figure 4. Risk of bias graph across clinical trials. Low risk of bias: green; Some concerns of bias: yellow;

High risk of bias: red.

\subsection{Meta-Analysis and Meta-Regression}

Only 11 clinical trials had common quality and variables needed to be used in the meta-analysis. These 11 trials worked with a total of 15 groups. The final size of the sample was comprised of 272 individuals, all with $\mathrm{CD}$, to which an EN treatment had been given. The common variables were the CDAI, the CRP, and the ESR, and the co-variables type of nutrition, age, and duration of the intervention. Figure 5 shows the effect size of the use of EN. For the three indicators of disease, the effects were positive when comparing the situation at the start and finish of the treatment with EN independently, if the situation with fixed effects (less probable) or random effects (more acceptable) is considered.

\begin{tabular}{|c|c|c|c|c|c|c|}
\hline \multirow[b]{2}{*}{ Study } & \multicolumn{5}{|c|}{ Before } & After \\
\hline & Total & Mean & SD & Total & Mean & SD \\
\hline${ }^{*} \mathrm{~S}$. Verma et al 2000 & 10 & 303.00 & 27.00 & 10 & 97.00 & 11.00 \\
\hline \#S. Verma et al 2000 & 11 & 359.00 & 67.00 & 11 & 112.00 & 19.00 \\
\hline *Dawn M. Wiese et al 2011 & 20 & 161.65 & 185.70 & 20 & 188.90 & 290.00 \\
\hline${ }^{\star} Y u n$ Feng et al 2013 & 8 & 265.80 & 25.93 & 8 & 143.00 & 18.57 \\
\hline `ZZhen Guo et al 2013 & 13 & 232.20 & 49.80 & 13 & 84.70 & 39.30 \\
\hline \#Dong Hu et al 2014 & 59 & 188.20 & 17.46 & 59 & 92.90 & 10.95 \\
\hline $\begin{array}{l}\text { Fixed effect model } \\
\text { Random effects model } \\
\text { Heterogeneity: } I^{2}=97 \%[96 \%\end{array}$ & 121 & & & 12 & & $0.01)$ \\
\hline
\end{tabular}

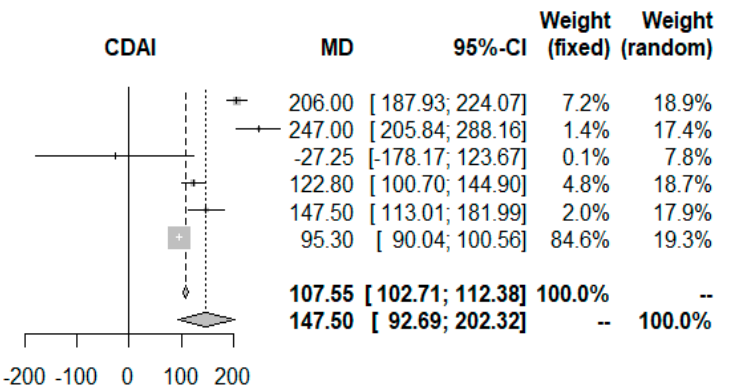

(a)

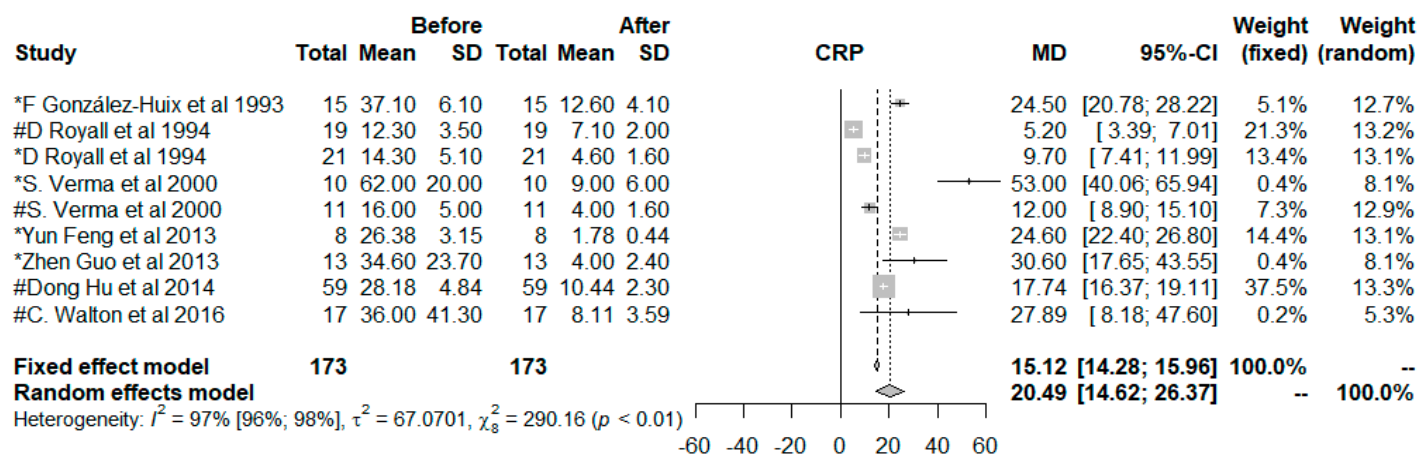

(b)

Figure 5. Cont. 


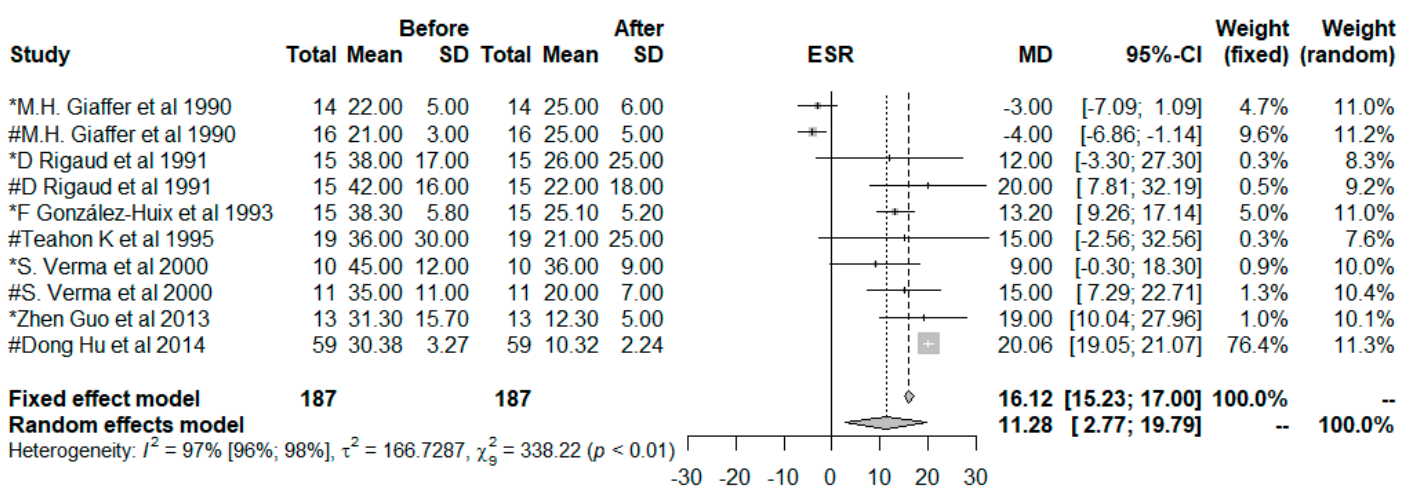

(c)

Figure 5. Forest plot for the (a) Crohn's disease activity index (CDAI), (b) C-reactive protein (CRP), (c) erythrocyte sedimentation rate (ESR). * Polymeric nutrition, \# Elemental nutrition.

The influence of each study on the results of the meta-analysis are shown on Table 2, considering a model of random effects. Figure 6 shows this influence through the Baujat plot. The numbers shown in the figure correspond to the articles shown in the table in the ID column.

Table 2. Influence analysis in meta-analysis using leave-one-out method (random effect).

\begin{tabular}{ccccccc}
\hline & & & \multicolumn{3}{c}{$\begin{array}{c}\text { Meta-Analysis for: } \\
\text { Effect Size (\%Heterogeneity) }\end{array}$} \\
\hline ID & Omitting & KN & n & CDAI & CRP & ESR \\
\hline 1 & M.H. Giaffer et al. 1990 & Pol & 14 & & & $13.0(96.8 \%)$ \\
2 & M.H. Giaffer et al. 1990 & Elm & 16 & & & $13.1(93.7 \%)$ \\
3 & D. Rigaud et al. 1991 & Pol & 15 & & & $11.2(97.6 \%)$ \\
4 & D. Rigaud et al. 1991 & Elm & 15 & & $20.0(97.4 \%)$ & $11.1(97.6 \%)$ \\
5 & F. Glez.-Huix et al. 1993 & Pol & 15 & & $22.2(95.1 \%)$ & \\
6 & D. Royall et al. 1994 & Elm & 19 & & $22.3(97.4 \%)$ & \\
7 & D. Royall et al. 1994 & Pol & 21 & & & $11.0(97.6 \%)$ \\
8 & Teahon K et al. 1995 & Elm & 19 & & & $11.5(97.6 \%)$ \\
9 & S. Verma et al. 2000 & Pol & 10 & $136.9(94.0 \%)$ & $17.5(97.3 \%)$ & $10.9(97.6 \%)$ \\
10 & S. Verma et al. 2000 & Elm & 11 & $128.0(97.2 \%)$ & $21.9(97.6 \%)$ & \\
11 & D. M. Wiese et al. 2011 & Pol & 20 & $162.3(97.8 \%)$ & & $19.7(96.6 \%)$ \\
12 & Yun Feng et al. 2013 & Pol & 8 & $150.3(97.9 \%)$ & $19.7(97.6 \%)$ \\
13 & Zhen Guo et al. 2013 & Pol & 13 & $146.7(97.8 \%)$ & $19.6(97.5 \%)$ & $10.4(97.6 \%)$ \\
14 & Dong Hu et al. 2014 & Elm & 59 & $162.7(92.6 \%)$ & $21.5(97.4 \%)$ & $9.8(91.2 \%)$ \\
15 & C. Walton et al. 2016 & Elm & 17 & & $20.1(97.6 \%)$ & \\
& Pooled estimate & & & $145.7(97.4 \%)$ & $20.5(97.2 \%)$ & $11.3(97.4 \%)$ \\
\hline
\end{tabular}

KN: Kind of nutrition; Pol: Polymeric nutrition; Elm: Elemental nutrition; CDAI: Crohn's disease activity index; VHAI: Van Hees activity index; CRP: C-reactive protein; ESR: erythrocyte sedimentation rate.

The results show that the articles did not influence the results in the case of the CDAI and the ESR, however, study 6 (D. Royall et al. 1994 with Elemental Nutrition) and to a lesser degree, study 12 (Yun Feng et al. 2013 with Polymeric Nutrition) may compromise the results of the meta-analysis for the CRP. However, the heterogeneity, omitting these works, was $95.1 \%$ and $96.6 \%$ when compared to the overall $97.2 \%$, therefore, a great influence of the CRP on the meta-analysis could not be determined.

A funnel plot represents the effects observed in the different studies ( $x$-axis), and the standard error ( $y$-axis). In the absence of heterogeneity and publication bias, the dots shown in the funnel plot should jointly adopt the aspect of a funnel, with the wider part corresponding to the smaller and more precise studies. A lack of symmetry could be due to this publication bias. The funnel plot is shown in Figure 7 , where a lack of symmetry can be observed. Therefore, the non-parametric analysis proposed by Duval and Tweedie to analyze this asymmetry should show a lack of articles, and therefore a publication bias. 
The results of this non-parametric analysis for the fixed-effects model and the random-effects model are shown in Table 3. These results show a possible publication bias in the three variables studied, if a fixed-effects model is assumed; however, the random-effects models did not show this bias.

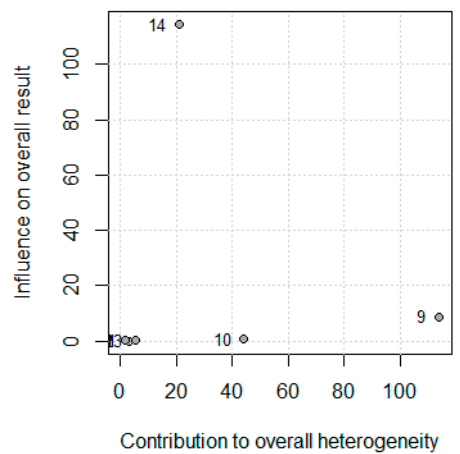

(a) CDAI

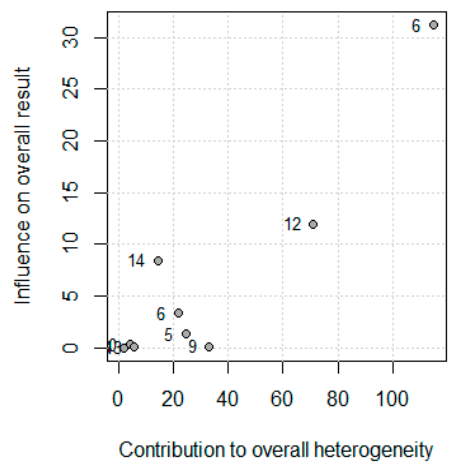

(b) CRP

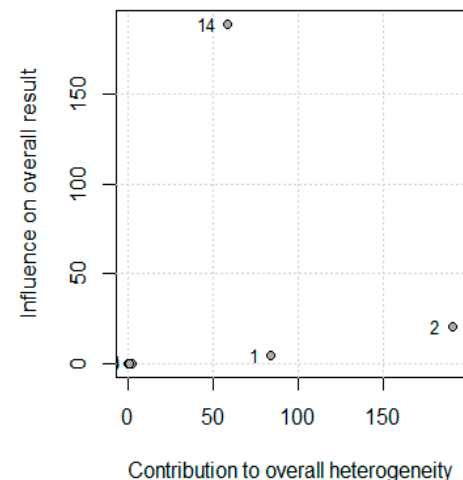

(c) ESR

Figure 6. Baujat plot for the (a) Crohn's disease activity index (CDAI), (b) C-reactive protein (CRP), and (c) erythrocyte sedimentation rate (ESR). The correspondence between the study and the number is shown in Table 2 (ID, Omitting).

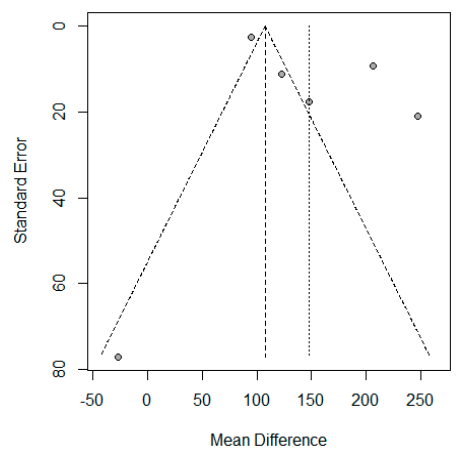

(a)

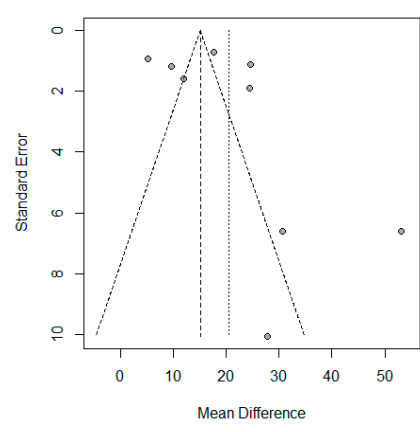

(b)

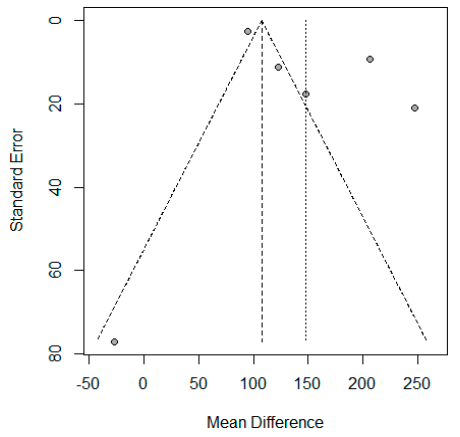

(c)

Figure 7. Funnel plot for the (a) Crohn's disease activity index (CDAI), (b) C-reactive protein (CRP), and (c) erythrocyte sedimentation rate (ESR).

Table 3. Number of studies that should be added and the estimated effect size.

\begin{tabular}{|c|c|c|c|c|c|c|}
\hline & \multicolumn{4}{|c|}{ Trim-and-Fill Method } & \multirow{2}{*}{\multicolumn{2}{|c|}{$\begin{array}{c}\text { Copas Method } \\
\text { Random Model }\end{array}$}} \\
\hline & \multicolumn{2}{|c|}{ Fix Model } & \multicolumn{2}{|c|}{ Random Model } & & \\
\hline & $\mathrm{N}^{\circ}$ Studies & $\begin{array}{c}\text { Effect Size } \\
\text { Estimated } 95 \% \mathrm{CI}\end{array}$ & $\mathbf{N}^{0}$ Studies & $\begin{array}{c}\text { Effect Size } \\
\text { Estimated } 95 \% \mathrm{CI}\end{array}$ & $\mathbf{N}^{o}$ Studies & $\begin{array}{c}\text { Effect Size } \\
\text { Estimated } 95 \% \mathrm{CI}\end{array}$ \\
\hline CDAI & 2 & $98.9[43.9 ; 153.8]$ & 0 & No Changes & 0 & No Changes \\
\hline CRP & 3 & $15.3[9.7 ; 20.9]$ & 0 & No Changes & 4 & $18.0[12.1 ; 23.9]$ \\
\hline ESR & 5 & 19.3 [11.2;27.4] & 0 & No Changes & 0 & No Changes \\
\hline
\end{tabular}

Crohn's disease activity index (CDAI); C-reactive protein (CRP); and erythrocyte sedimentation rate (ESR).

With respect to the meta-regression, the results are shown in Table 4 . There was a dependence of the CDAI score with the period, losing efficacy in prolonged interventions $(p<0.05)$. The CRP showed better results in the EN when using polymeric formulas that were elemental $(p<0.001)$. 
Table 4. Meta-regression.

\begin{tabular}{ccccc}
\hline Result & & \multicolumn{3}{c}{ Co-Variable $\begin{array}{c}\text { Test of } \\
\text { Moderators }\end{array}$} \\
\hline & Intercep & KN $^{*}$ & QM & $p$-Value \\
\hline CDAI & 167.9 & -33.8 & 0.289 & 0.591 \\
CRP & 13.7 & 12.6 & 3.977 & $<0.001$ \\
ESR & 12.9 & -3.0 & 0.106 & 0.745 \\
& Intercep & Age & QM & $p$-Value \\
CDAI & 225.5 & -2.38 & 0.203 & 0.652 \\
CRP & 52.9 & -1.0 & 0.985 & 0.321 \\
ESR & 48.3 & -1.1 & 1.555 & 0.212 \\
& Intercep & Period & QM & $p$-Value \\
CDAI & 235.5 & -1.9 & 5.662 & 0.017 \\
CRP & 21.4 & -0.0 & 0.006 & 0.941 \\
ESR & 2.5 & 0.2 & 1.551 & 0.213 \\
\hline
\end{tabular}

$\mathrm{KN}$ : Kind of nutrition, ${ }^{*}$ Basis elemental enteral nutrition. Crohn's disease activity index (CDAI), C-reactive protein (CRP), and erythrocyte sedimentation rate (ESR).

\section{Discussion}

Our results included 30 studies (1070 participants). All trials included had a broad scope and had a very varied methodological and clinical heterogeneity. The variables collected were very diverse, with CDAI, CRP, and ESR being the most common. The sample sizes of the studies included were generally small $(n<30)$, thus, a meta-analysis was needed in order to arrive at better conclusions.

A cure for IBD is not known, however, there is evidence of remission and improvement of the symptoms with EEN, which implies the exclusive consumption of an elemental or polymeric substance for many weeks [50], as shown by many of our results. Despite the lack of correlation between IBDQ and the CDAI, correlations were observed between both indexes starting at week 4 of the treatment. A study that focused on the gall bladder was even found, which showed its improvement after day 36 of treatment administration; therefore, aside from reducing the activity or inducing the remission of the disease, this diet could have beneficial effects on organs related with the digestive system [23,25].

The EN formulas tended to contain macronutrients such as amino acids or simple carbohydrates, along with micronutrients such as vitamins. The proteins, carbohydrates, and fats do not reach the ilium or the colon as they are absorbed in the duodenum and jejunum. As for the amino acids they contain, they were named as elemental formulas if they contained free amino acids, semi-elemental if they contained peptides, and polymeric if they contained whole proteins [51]. Different formulations exist, but the ones that do seem to have a positive effect on the maintenance and remission of the disease are elemental and polymeric diets $[10,22]$. The efficacy of an EN diet does not depend much on it being elemental or polymeric, as shown by some of our results [42,44], since, a priori, both have the same potential for inducing a remission [32,39,46]. However, the meta-regression conducted indicated that a polymeric diet could decrease the CRP better than an elemental one. Additionally, a distinction could be made between them when looking at the economic burden entailed by the use of one or the other and the acceptability by the patients, meaning that, in the adherence to the dietary treatment, the polymeric ones tend to be more accepted by the patients, as they are better tasting $[52,53]$. The elemental foods are less tolerated with mouth feeding, and generally require a nasogastric tube, which entails complications and patient discomfort. In contrast, the polymeric EN is more tolerable through the mouth by patients, making it the first option for the ill [33,54].

As for the formulation of the EN, studies have also been conducted on the benefits or not of an EN diet rich in fats as opposed to an elemental EN. Just as in other studies, the results of the clinical trials are controversial. Some studies have demonstrated the beneficial effect of the enteral formula rich in fats [55], while others did not show any effect [56] or less beneficial effects [29]. Despite what has been said, some studies have suggested that an EN high in fats could improve gastrointestinal 
motility and improve the ilium after an operation [57], reducing damage to the intestinal mucosa barrier and the underlying mechanism that could be associated with its antioxidant action after surgical intervention [58].

EEN, combined with some types of medication such as antibiotics [59], seem to improve the disease's symptoms. Just as shown by our results, EN combined with other types of pharmaceuticals such as prednisone, corticosteroids, and sulfasalazines show a significantly continuous high rate of remission $[41,60]$. On the other hand, the combination of EN with steroids does not seem to have significant differences in the probability of a relapse [40], perhaps because the steroids do not address the damage produced in the intestinal mucosa, which is the greatest predictor of complications over time $[61,62]$.

Although the mechanism that nurtures the healing of the mucosa by the EN has not been completely determined as of yet, it has been shown that a polymeric formula was as effective as the Infliximab inhibitor of tumor necrosis factor (TNF)- $\alpha$, and is higher than the hydrocortisone in the maintenance of the function of the intestinal barrier [63]. This is perhaps the reason why significant differences were not found in a study conducted by Gasull et al. in 2001 that utilized two polymeric EN formulas, with the response being similar in both [30]. Additionally, in another study conducted with two polymeric formulas for five weeks, a significant relationship was not found between the treatment with different EN and the changes produced at the level of the disease's activity [37].

As for the use of elemental and semi-elemental EN, the results were very similar. For example, Mansuf et al. achieved the clinical remission of 16 patients in four weeks with both formulas, and the reduction of the CRP was significant in both groups [36]. The mechanism of action of the semi-elemental diet could be multifunctional, just like as the elemental one, decreasing the intestinal permeability and thus decreasing the loss of fluid. The semi-elemental diet could also reduce the commensal intestinal bacteria that play a role in intestinal inflammation $[64,65]$. Thus, the use of these types of diets is advisable, either with the use of an elemental or semi-elemental formula for the management of different gastro-intestinal disorders [66].

In 2013, Yun Feng et al. [24] found significant differences between groups subjected to EEN and EN plus an oral diet, although it is interesting to note how the patients refer to a greater subjective well-being when they take EN together with the oral diet when compared to those who are not treated with supplemented EN, despite the biochemical parameters being very similar [21,49]. Some studies suggest that a partial enteral nutrition supplemented with different diets such as elimination, anti-inflammatory, auto-immune diets, or diets low in FODMAP (Fermentable Oligo-, Di-, Mono-saccharides and Polyols) could be beneficial for UC and CD [25,32], although larger controlled assays are needed to back their use [67]. Even patients who were subjected to EN before their operation experienced benefits, not only in their nutritional state, but also with a reduction of inflammation in their disease [68], with patients also experiencing improvements after said intervention [27].

Historically, EN was used and is used as a complementary nutritional treatment for patients with complicated IBD that leads to worrying malnutrition, thus improving their nutritional state [53]. However, the meta-regression from our study showed an inverse relationship between the period of treatment with EN and the improvement shown through the CDAI, that foreseeably, the patients who are subjected to prolonged EN could stop noticing its benefits.

The EN was utilized as an induction therapy for active IBD [53], but it is important to know which EN formulas can be used to boost their anti-inflammatory effects, as there is evidence that supplementary EN is not sufficient for inducing remission, so that it would have to be used exclusively to be able to obtain its anti-inflammatory effect $[69,70]$. At present, it is well-established that EEN has a strong anti-inflammatory effect with a reduction in the systemic and mucosa inflammatory parameters in a few days, however, the EEN as a long-term therapy is still a challenge, given its lack of palatability and the lack of data to analyze the efficiency of EEN as a maintenance diet [71].

Diverse studies have shown that clinical remission and healing of the mucosa is possible through different nutritional regimes [72]. As for the debate about which is healthier, EN or PN, our results 
showed that there are studies in which the effectiveness of both seems to be significantly the same for the improvement of the CDAI $[45,48]$. Bearing in mind that the dietary antigens could be important stimulants for the immune system of the mucosa, intestinal rest with total parenteral nutrition (TPN) is considered as the main option for achieving this rest and for correcting possible nutritional deficits [73]; however when compared to the EN, it does not seem to provide greater benefits. In fact, in one of the studies included in our review [47], EN was the one that seemed to provide the greatest benefits to the patients and to reduce the costs, personal as well as economic, of the different dietary treatments [74].

According to European guidelines, the acceptability and the obligatory compliance of the EN are the greatest obstacles found by different researchers when dealing with EN studies. There are clear differences between the studies shown in terms of healing of the mucosa, and therefore the remission of the activity of the disease, which makes them difficult to compare. What is known, however, is that the EEN is a real alternative to immunosuppressive therapy, which exerts its main therapeutic effect on the microbiota, thus reducing intestinal permeability, enhancing barrier defense, and promoting a reduction of pro-inflammatory cytokines $[75,76]$.

This study is not exempt of limitations. With respect to the systematic review, seven articles were not recovered, so our results could be altered. However, the small variability observed through the meta-analysis implies that these articles could substantially vary the results obtained, and in fact, the sensitivity study that analyzed the publication bias showed little alterations on the effect size as well as its confidence interval. Although the quality of these studies has not been introduced in the meta-regression, all the articles that were utilized with this technique were considered to have sufficient quality, so we do not believe that the quality could introduce bias in the findings.

\section{Conclusions}

EN has been shown to have efficacy for the treatment of CD and is compatible with other medicines. As for the CDAI or the rates of remission, there were no differences between EN and PN. Polymeric formulas, when compared to elemental ones, have shown better results with respect to the CRP. The long-term treatment could dilute the good CDAI results that are obtained at the start of EN treatment.

Author Contributions: Conceptualization, J.M.C., A.G.-H., S.G.-S., and C.A.; Methodology, J.M.C., C.A., and P.C.; Formal analysis, J.M.C., I.C., and P.C.; Investigation, J.M.C., A.G.-H., S.G.-S., and I.C.; Writing-original draft preparation, J.M.C. and P.C.; Writing-review and editing, A.G.-H., S.G.-S., I.C., and J.T.; Visualization, J.T.; Supervision, J.T. and P.C.

Funding: This research received no external funding.

Conflicts of Interest: The authors declare no conflict of interest.

\section{References}

1. Celiberto, L.S.; Graef, F.A.; Healey, G.R.; Bosman, E.S.; Jacobson, K.; Sly, L.M.; Vallance, B.A. Inflammatory bowel disease and immunonutrition: Novel therapeutic approaches through modulation of diet and the gut microbiome. Immunology 2018, 155, 36-52. [CrossRef] [PubMed]

2. Cohen, L.J.; Cho, J.H.; Gevers, D.; Chu, H. Genetic Factors and the Intestinal Microbiome Guide Development of Microbe-Based Therapies for Inflammatory Bowel Diseases. Gastroenterology 2019, 156, 2174-2189. [CrossRef] [PubMed]

3. Coward, S.; Clement, F.; Benchimol, E.I.; Bernstein, C.N.; Avina-Zubieta, J.A.; Bitton, A.; Carroll, M.W.; Hazlewood, G.; Jacobson, K.; Jelinski, S.; et al. Past and Future Burden of Inflammatory Bowel Diseases Based on Modeling of Population-Based Data. Gastroenterology 2019, 156, 1345-1353. [CrossRef] [PubMed]

4. Ng, S.C.; Shi, H.Y.; Hamidi, N.; Underwood, F.E.; Tang, W.; Benchimol, E.I.; Panaccione, R.; Ghosh, S.; Wu, J.C.Y.; Chan, F.K.L.; et al. Worldwide incidence and prevalence of inflammatory bowel disease in the 21st century: A systematic review of population-based studies. Lancet 2017, 390, 2769-2778. [CrossRef] 
5. Reddavide, R.; Rotolo, O.; Caruso, M.G.; Stasi, E.; Notarnicola, M.; Miraglia, C.; Nouvenne, A.; Meschi, T.; De' Angelis, G.L.; Di Mario, F.; et al. The role of diet in the prevention and treatment of inflammatory bowel diseases. Acta Biomed. 2018, 89, 60-75.

6. Eom, T.; Kim, Y.S.; Choi, C.H.; Sadowsky, M.J.; Unno, T. Current understanding of microbiota- and dietary-therapies for treating inflammatory bowel disease. J. Microbiol. 2018, 56, 189-198. [CrossRef]

7. Abegunde, A.T.; Muhammad, B.H.; Bhatti, O.; Ali, T. Environmental risk factors for inflammatory bowel diseases: Evidence based literature review. World J. Gastroenterol. 2016, 22, 6296-6317. [CrossRef]

8. Aleksandrova, K.; Romero-Mosquera, B.; Hernandez, V. Diet, Gut Microbiome and Epigenetics: Emerging Links with Inflammatory Bowel Diseases and Prospects for Management and Prevention. Nutrients 2017, 9, 962. [CrossRef]

9. Ruemmele, F.M. Role of Diet in Inflammatory Bowel Disease. Ann. Nutr. Metab. 2016, 68, 33-41. [CrossRef]

10. Walton, C.; Montoya, M.P.; Fowler, D.P.; Turner, C.; Jia, W.; Whitehead, R.N.; Griffiths, L.; Waring, R.H.; Ramsden, D.B.; Cole, J.A.; et al. Enteral feeding reduces metabolic activity of the intestinal microbiome in Crohn's disease: An observational study. Eur. J. Clin. Nutr. 2016, 70, 1052-1056. [CrossRef]

11. Kakodkar, S.; Mutlu, E.A. Diet as a Therapeutic Option for Adult Inflammatory Bowel Disease. Gastroenterol. Clin. N. Am. 2017, 46, 745-767. [CrossRef] [PubMed]

12. Hansen, T.; Duerksen, D.R. Enteral nutrition in the management of pediatric and adult crohn's disease. Nutrients 2018, 10, 537. [CrossRef] [PubMed]

13. Guagnozzi, D.; González-Castillo, S.; Olveira, A.; Lucendo, A.J. Nutritional treatment in inflammatory bowel disease. An update. Rev. Esp. Enferm. Dig. 2012, 104, 479-488. [CrossRef] [PubMed]

14. Moher, D.; Liberati, A.; Tetzlaff, J.; Altman, D.G. Preferred reporting items for systematic reviews and meta-analyses: The PRISMA statement. J. Clin. Epidemiol. 2009, 62, 1006-1012. [CrossRef] [PubMed]

15. Sterne, J.A.C.; Savovic, J.; Page, M.J.; Elbers, R.G.; Blencowe, N.S.; Boutron, I.; Cates, C.J.; Cheng, H.-Y.; Corbett, M.S.; Eldridge, S.M.; et al. RoB 2: A revised tool for assessing risk of bias in randomised trials. BMJ 2019, 366, 14898. [CrossRef] [PubMed]

16. Baujat, B.; Mahé, C.; Pignon, J.P.; Hill, C. A graphical method for exploring heterogeneity in meta-analyses: Application to a meta-analysis of 65 trials. Stat. Med. 2002, 21, 2641-2652. [CrossRef]

17. Duval, S.; Tweedie, R. A Nonparametric "Trim and Fill" Method of Accounting for Publication Bias in Meta-Analysis. J. Am. Stat. Assoc. 2000, 95, 89-98.

18. Copas, J.B.; Shi, J.Q. A sensitivity analysis for publication bias in systematic reviews. Stat. Methods Med. Res. 2001, 10, 251-265. [CrossRef]

19. Schwarzer, G. meta: An R package for meta-analysis. R News 2007, 7, 40-45.

20. Schwarzer, G.; Carpenter, J.R.; Rüker, G. Metasens: Advanced Statistical Methods to Model and Adjust for Bias in Meta-Analysis. R package version 0.4-0. 2019. Available online: https://CRAN.R-project.org/ package $=$ metasens (accessed on 29 October 2019).

21. Sokulmez, P.; Demirbag, A.E.; Arslan, P.; Disibeyaz, S. Effects of enteral nutritional support on malnourished patients with inflammatory bowel disease by subjective global assessment. Turk. J. Gastroenterol. 2014, 25, 493-507. [CrossRef]

22. Hu, D.; Ren, J.; Wang, G.; Li, G.; Liu, S.; Yan, D.; Gu, G.; Zhou, B.; Wu, X.; Chen, J.; et al. Exclusive enteral nutritional therapy can relieve inflammatory bowel stricture in Crohn's disease. J. Clin. Gastroenterol. 2014, 48, 790-795. [CrossRef] [PubMed]

23. Guo, Z.; Wu, R.; Zhu, W.; Gong, J.; Zhang, W.; Li, Y.; Gu, L.; Li, N.; Li, J. Effect of exclusive enteral nutrition on health-related quality of life for adults with active Crohn's disease. Nutr. Clin. Pract. 2014, 28, 499-505. [CrossRef] [PubMed]

24. Feng, Y.; Li, Y.; Mei, S.; Zhang, L.; Gong, J.; Gu, L.; Zhang, W.; Zhu, W.; Li, N.; Li, J. Exclusive enteral nutrition ameliorates mesenteric adipose tissue alterations in patients with active Crohn's disease. Clin. Nutr. 2013, 33, 850-858. [CrossRef] [PubMed]

25. Wiese, D.M.; Lashner, B.A.; Lerner, E.; Demichele, S.J.; Seidner, D.L. The effects of an oral supplement enriched with fish oil, prebiotics, and antioxidants on nutrition status in Crohn's disease patients. Nutr. Clin. Pract. 2011, 26, 463-473. [CrossRef] [PubMed]

26. Yamamoto, T.; Nakahigashi, M.; Umegae, S.; Matsumoto, K. Prospective clinical trial: Enteral nutrition during maintenance infliximab in Crohn's disease. J. Gastroenterol. 2010, 45, 24-29. [CrossRef] 
27. Yamamoto, T.; Nakahigashi, M.; Umegae, S.; Kitagawa, T.; Matsumoto, K. Impact of long-term enteral nutrition on clinical and endoscopic recurrence after resection for Crohn's disease: A prospective, non-randomized, parallel, controlled study. Aliment. Pharmacol. Ther. 2007, 25, 67-72. [CrossRef]

28. Takagi, S.; Utsunomiya, K.; Kuriyama, S.; Yokoyama, H.; Takahashi, S.; Iwabuchi, M.; Takahashi, H.; Takahashi, S.; Kinouchi, Y.; Hiwatashi, N.; et al. Effectiveness of an "half elemental diet" as maintenance therapy for Crohn's disease: A randomized-controlled trial. Aliment. Pharmacol. Ther. 2006, 24, 1333-1340. [CrossRef]

29. Bamba, T.; Shimoyama, T.; Sasaki, M.; Tsujikawa, T.; Fukuda, Y.; Koganei, K.; Hibi, T.; Iwao, Y.; Munakata, A.; Fukuda, S.; et al. Dietary fat attenuates the benefits of an elemental diet in active Crohn's disease: A randomized, controlled trial. Eur. J. Gastroenterol. Hepatol. 2003, 15, 151-157. [CrossRef]

30. Gassull, M.A.; Fernández-Bañares, F.; Cabré, E.; Papo, M.; Giaffer, M.H.; Sánchez-Lombraña, J.L.; Richart, C.; Malchow, H.; González-Huix, F.; Esteve, M. Fat composition may be a clue to explain the primary therapeutic effect of enteral nutrition in Crohn's disease: Results of a double blind randomised multicentre European trial. Gut 2002, 51, 164-168. [CrossRef]

31. Sakurai, T.; Matsui, T.; Yao, T.; Takagi, Y.; Hirai, F.; Aoyagi, K.; Okada, M. Short-term efficacy of enteral nutrition in the treatment of active Crohn's disease: A randomized, controlled trial comparing nutrient formulas. JPEN J. Parenter. Enteral Nutr. 2002, 26, 98-103. [CrossRef]

32. Verma, S.; Kirkwood, B.; Brown, S.; Giaffer, M.H. Oral nutritional supplementation is effective in the maintenance of remission in Crohn's disease. Dig. Liver Dis. 2000, 32, 769-774. [CrossRef]

33. Verma, S.; Brown, S.; Kirkwood, B.; Giaffer, M.H.H. Polymeric versus elemental diet as primary treatment in active Crohn's disease: A randomized, double-blind trial. Am. J. Gastroenterol. 2000, 95, 735-739. [CrossRef] [PubMed]

34. Schneeweiss, B.; Lochs, H.; Zauner, C.; Fischer, M.; Wyatt, J.; Maier-Dobersberger, T.; Schneider, B. Energy and substrate metabolism in patients with active Crohn's disease. J. Nutr. 1999, 129, 844-848. [CrossRef] [PubMed]

35. Royall, D.; Greenberg, G.R.; Allard, J.P.; Baker, J.P.; Jeejeebhoy, K.N. Total enteral nutrition support improves body composition of patients with active Crohn's disease. JPEN J. Parenter. Enteral Nutr. 1995, 19, 95-99. [CrossRef] [PubMed]

36. Mansfield, J.C.; Giaffer, M.H.; Holdsworth, C.D. Controlled trial of oligopeptide versus amino acid diet in treatment of active Crohn's disease. Gut 1995, 36, 60-66. [CrossRef] [PubMed]

37. Teahon, K.; Pearson, M.; Smith, T.; Bjarnason, I. Alterations in nutritional status and disease activity during treatment of crohn's disease with elemental diet. Scand. J. Gastroenterol. 1995, 30, 54-60. [CrossRef] [PubMed]

38. Stolk, M.F.; Van Erpecum, K.J.; Hiemstra, G.; Jansen, J.B.; Van Berge-Henegouwen, G.P. Gallbladder motility and cholecystokinin release during long-term enteral nutrition in patients with Crohn's disease. Scand. J. Gastroenterol. 1994, 29, 934-939. [CrossRef]

39. Royall, D.; Jeejeebhoy, K.N.; Baker, J.P.; Allard, J.P.; Habal, F.M.; Cunnane, S.C.; Greenberg, G.R. Comparison of amino acid v peptide based enteral diets in active Crohn's disease: Clinical and nutritional outcome. Gut 1994, 35, 783-787. [CrossRef]

40. Gonzalez-Huix, F.; de Leon, R.; Fernandez-Banares, F.; Esteve, M.; Cabre, E.; Acero, D.; Abad-Lacruz, A.; Figa, M.; Guilera, M.; Planas, R.; et al. Polymeric enteral diets as primary treatment of active Crohn's disease: A prospective steroid controlled trial. Gut 1993, 34, 778-782. [CrossRef]

41. Hirakawa, H.; Fukuda, Y.; Tanida, N.; Hosomi, M.; Shimoyama, T. Home elemental enteral hyperalimentation $(\mathrm{HEEH})$ for the maintenance of remission in patients with Crohn's disease. Gastroenterol. JPN 1993, 28, 379-384. [CrossRef]

42. Rigaud, D.; Cosnes, J.; Le Quintrec, Y.; René, E.; Gendre, J.P.; Mignon, M. Controlled trial comparing two types of enteral nutrition in treatment of active Crohn's disease: Elemental versus polymeric diet. Gut 1991, 32, 1492-1497. [CrossRef] [PubMed]

43. Lochs, H.; Steinhardt, H.J.R.G.; Klaus-wentz, B.; Zeitz, M.; Vogelsang, H.; Sommer, H.; Fleig, W.E.; Bauer, P.; Schirrmeister, J.R.G.; Malchow, H. Comparison of Enteral Nutrition and Drug Treatment in Active Crohn's Disease Cooperative. Gastroenterology 1991, 101, 881-888. [CrossRef]

44. Raouf, A.H.; Hildrey, V.; Daniel, J.; Walker, R.J.; Krasner, N.; Elias, E.; Rhodes, J.M. Enteral feeding as sole treatment for Crohn's disease: Controlled trial of whole protein v amino acid based feed and a case study of dietary challenge. Gut 1991, 32, 702-707. [CrossRef] [PubMed] 
45. Wright, R.A.; Adler, E.C. Peripheral parenteral nutrition is no better than enteral nutrition in acute exacerbation of Crohn's disease: A prospective trial. J. Clin. Gastroenterol. 1990, 12, 396-399. [CrossRef]

46. Giaffer, M.H.; North, G.; Holdsworth, C.D. Controlled trial of polymeric versus elemental diet in treatment of active Crohn's disease. Lancet 1990, 335, 816-819. [CrossRef]

47. Abad-Lacruz, A.; González-Huix, F.; Esteve, M.; Fernández-Bañares, F.; Cabré, E.; Boix, J.; Acero, D.; Humbert, P.; Gassull, M.A. Liver function tests abnormalities in patients with inflammatory bowel disease receiving artificial nutrition: A prospective randomized study of total enteral nutrition vs total parenteral nutrition. JPEN J. Parenter. Enteral Nutr. 1990, 14, 618-621. [CrossRef]

48. Greenberg, G.R.; Fleming, C.R.; Jeejeebhoy, K.N.; Rosenberg, I.H.; Sales, D.; Tremaine, W.J. Controlled trial of bowel rest and nutritional support in the management of Crohn's disease. Gut 1988, 29, 1309-1315. [CrossRef]

49. Harries, A.D.; Jones, L.A.; Danis, V.; Fifield, R.; Heatley, R.V.; Newcombe, R.G.; Rhodes, J. Controlled trial of supplemented oral nutrition in Crohn's disease. Lancet 1983, 1, 887-890. [CrossRef]

50. Cuív, P.Ó.; Begun, J.; Keely, S.; Lewindon, P.J.; Morrison, M. Towards an integrated understanding of the therapeutic utility of exclusive enteral nutrition in the treatment of Crohn's disease. Food Funct. 2016, 7, 1741-1751. [CrossRef]

51. Dupont, B.; Dupont, C.; Justum, A.-M.; Piquet, M.-A.; Reimund, J.-M. Enteral nutrition in adult Crohn's disease: Present status and perspectives. Mol. Nutr. Food Res. 2008, 52, 875-884. [CrossRef]

52. Halmos, E.P.; Gibson, P.R. Dietary management of IBD—insights and advice. Nat. Rev. Gastroenterol. Hepatol. 2015, 12, 133-146. [CrossRef] [PubMed]

53. Ruemmele, F.M.; Pigneur, B.; Garnier-Lengliné, H. Enteral Nutrition as Treatment Option for Crohn's Disease: In Kids Only? Nestle Nutr. Inst. Workshop Ser. 2014, 79, 115-123. [PubMed]

54. Rubio, A.; Pigneur, B.; Garnier-Lengliné, H.; Talbotec, C.; Schmitz, J.; Canioni, D.; Goulet, O.; Ruemmele, F.M. The efficacy of exclusive nutritional therapy in paediatric Crohn's disease, comparing fractionated oral vs. continuous enteral feeding. Aliment. Pharmacol. Ther. 2011, 33, 1332-1339. [CrossRef] [PubMed]

55. Mohri, T.; Matsuda, H.; Kubo, N.; Inadome, N.; Nakamori, Y.; Fujimi, S.; Yoshioka, T. The effect on glycemic control of a low-carbohydrate, high-fat enteral formula in critically ill patients admitted to a trauma and critical care center. Nihon Kyukyu Igakukai Zasshi 2011, 22, 871-877. [CrossRef]

56. Wewalka, M.; Drolz, A.; Zauner, C. Influence of fat-based versus glucose-based enteral nutrition formulas on glucose homeostasis. Crit. Care 2013, 17, P250.

57. Lubbers, T.; Luyer, M.D.P.; de Haan, J.-J.; Hadfoune, M.; Buurman, W.A.; Greve, J.W.M. Lipid-Rich Enteral Nutrition Reduces Postoperative Ileus in Rats via Activation of Cholecystokinin-Receptors. Ann. Surg. 2009, 249, 481-487. [CrossRef]

58. Tan, S.-J.; Yu, C.; Yu, Z.; Lin, Z.-L.; Wu, G.-H.; Yu, W.-K.; Li, J.-S.; Li, N. High-fat enteral nutrition reduces intestinal mucosal barrier damage after peritoneal air exposure. J. Surg. Res. 2016, 202, 77-86. [CrossRef]

59. Xie, C.; Lin, J.; Su, J.; Ren, J. Synergistic effect of enteral nutrition on remission induction in a patient with penetrating Crohn disease. Medicine 2019, 98, e16750. [CrossRef]

60. Lochs, H.; Steinhardt, H.J.; Klaus-Wentz, B.; Zeitz, M.; Vogelsang, H.; Sommer, H.; Fleig, W.E.; Bauer, P.; Schirrmeister, J.; Malchow, H. Comparison of enteral nutrition and drug treatment in active Crohn's disease. Results of the European Cooperative Crohn's Disease Study. IV. Gastroenterology 1991, 101, 881-888. [CrossRef]

61. Papi, C.; Fascì-Spurio, F.; Rogai, F.; Settesoldi, A.; Margagnoni, G.; Annese, V. Mucosal healing in inflammatory bowel disease: Treatment efficacy and predictive factors. Dig. Liver Dis. 2013, 45, 978-985. [CrossRef]

62. Armuzzi, A.; Van Assche, G.; Reinisch, W.; de Chambrun, G.P.; Griffiths, A.; Sladek, M.; Preiss, J.C.; Lukas, M.; D'Haens, G. Results of the 2nd scientific workshop of the ECCO (IV): Therapeutic strategies to enhance intestinal healing in inflammatory bowel disease. J. Crohn's Colitis 2012, 6, 492-502. [CrossRef] [PubMed]

63. Nahidi, L.; Day, A.S.; Lemberg, D.A.; Leach, S.T. Differential effects of nutritional and non-nutritional therapies on intestinal barrier function in an in vitro model. J. Gastroenterol. 2012, 47, 107-117. [CrossRef] [PubMed]

64. Teahon, K.; Smethurst, P.; Pearson, M.; Levi, A.J.; Bjarnason, I. The effect of elemental diet on intestinal permeability and inflammation in Crohn's disease. Gastroenterology 1991, 101, 84-89. [CrossRef] 
65. Ahmad, S.J.; Khan, A.; Madhotra, R.; Exadaktylos, A.K.; Milioto, M.E.; Macfaul, G.; Rostami, K. Semi-elemental diet is effective in managing high output ileostomy; a case report. Gastroenterol. Hepatol. Bed Bench 2019, 12, 169-173. [PubMed]

66. Rostami, K.; Al Dulaimi, D. Elemental diets role in treatment of high ileostomy output and other gastrointestinal disorders. Gastroenterol. Hepatol. Bed Bench 2015, 8, 71-76.

67. Damas, O.M.; Garces, L.; Abreu, M.T. Diet as Adjunctive Treatment for Inflammatory Bowel Disease: Review and Update of the Latest Literature. Curr. Treat. Options Gastroenterol. 2019, 17, 313-325. [CrossRef]

68. Voitk, A.J.; Echave, V.; Feller, J.H.; Brown, R.A.; Gurd, F.N. Experience with elemental diet in the treatment of inflammatory bowel disease. Is this primary therapy? Arch. Surg. 1973, 107, 329. [CrossRef]

69. Ruemmele, F.M.; Roy, C.C.; Levy, E.; Seidman, E.G. Nutrition as primary therapy in pediatric Crohn's disease: Fact or fantasy? J. Pediatr. 2000, 136, 285-291. [CrossRef]

70. Johnson, T.; Macdonald, S.; Hill, S.M.; Thomas, A.; Murphy, M.S. Treatment of active Crohn's disease in children using partial enteral nutrition with liquid formula: A randomised controlled trial. Gut 2006, 55, 356-361. [CrossRef]

71. Fell, J.M.; Paintin, M.; Arnaud-Battandier, F.; Beattie, R.M.; Hollis, A.; Kitching, P.; Donnet-Hughes, A.; MacDonald, T.T.; Walker-Smith, J.A. Mucosal healing and a fall in mucosal pro-inflammatory cytokine mRNA induced by a specific oral polymeric diet in paediatric Crohn's disease. Aliment. Pharmacol. Ther. 2000, 14, 281-289. [CrossRef]

72. Wedlake, L.; Slack, N.; Andreyev, H.J.N.; Whelan, K. Fiber in the treatment and maintenance of inflammatory bowel disease: A systematic review of randomized controlled trials. Inflamm. Bowel Dis. 2014, 20, 576-586. [CrossRef] [PubMed]

73. Scolapio, J.S. The Role of Total Parenteral Nutrition in the Management of Patients with Acute Attacks of Inflammatory Bowel Disease. J. Clin. Gastroenterol. 1999, 29, 223-224. [CrossRef] [PubMed]

74. Storck, L.J.; Imoberdorf, R.; Ballmer, P.E. Nutrition in Gastrointestinal Disease: Liver, Pancreatic, and Inflammatory Bowel Disease. J. Clin. Med. 2019, 8, 1098. [CrossRef] [PubMed]

75. Griffiths, A.M. Enteral Nutrition in the Management of Crohn's Disease. J. Parenter. Enter. Nutr. 2005, 29, S108-S117. [CrossRef]

76. Forbes, A.; Escher, J.; Hébuterne, X.; Kłęk, S.; Krznaric, Z.; Schneider, S.; Shamir, R.; Stardelova, K.; Wierdsma, N.; Wiskin, A.E.; et al. ESPEN guideline: Clinical nutrition in inflammatory bowel disease. Clin. Nutr. 2017, 36, 321-347. [CrossRef] 